\title{
Manifesto por uma Educação Ambiental indisciplinada
}

\section{Manifest for an unruly Environmental Education}

\section{Philippe Pomier Layrargues ${ }^{1}$}

1 Doutor em Ciências Sociais, Universidade de Brasília, Brasília, DF, Brasil - philippe.layrargues@gmail.com / 0000-00027684-7334

\section{Palavras-chave:}

Educação Ambiental.

Sujeito Ecopolítico. Anti

Ecologismo. Retrocesso

Ambiental. Pedagogia da Indignação.

\section{Keywords:}

Environmental

Education. Eco political Subject. Antiecologism. Environmental Setback. Pedagogy of Indignation.
RESUMO: O objetivo deste ensaio é o de trazer ao debate algumas leituras interpretativas da conjuntura ecopolítica nacional - demarcada pelo vertiginoso retrocesso ambiental -, combinada com a conjuntura global do emergente colapso climático, no marco histórico dos primeiros seis meses do governo Bolsonaro, regime político declaradamente pautado pelo signo do antiecologismo e pela crença negacionista climática. De posse desses subsídios conjunturais, nosso propósito é de refletir em que medida essa conjuntura interage com o contexto sociopolítico no campo da Educação Ambiental. A questão do debate gira em torno de saber se e como essa nova realidade ecopolítica desafia a capacidade de atualização da educação ambiental brasileira para reagir à altura da nova conjuntura da intensificação da luta ambiental democrática contra políticas ecocidas. O horizonte aqui é o de compreender sob quais condições a Educação Ambiental poderá ser afetada e modificada ante o traumático, intenso e multifacetado drama social ecopolítico brasileiro, drama social que comporta simultaneamente o risco da estagnação seguindo conformando um sujeito ecológico conservador e a oportunidade da mudança para a formação de um sujeito irreverentemente ecopolítico.

ABSTRACT: The aim of this essay is to bring to the debate some interpretative readings of the national ecopolitical conjuncture - marked by the vertiginous environmental setback - combined with the global conjuncture of the emerging climate collapse, within the historical framework of the first six months of the Bolsonaro government, a declared political regime by the sign of anti-ecologism and the climate negationist belief. With these conjunctural subsidies, our purpose is to reflect to what extent this conjuncture interacts with the socio-political context in the field of Environmental Education. The question of debate revolves around whether and how this new ecopolitical reality challenges the ability of Brazilian environmental education to be updated to respond to the new conjuncture of the intensification of the democratic environmental struggle against ecocidal policies. The horizon here is to understand under which conditions Environmental Education can be affected and modified in the face of the traumatic, intense and multifaceted Brazilian ecopolitical social drama, a social drama that simultaneously carries the risk of stagnation, continuing to shape a conservative ecological subject and the opportunity for change. for the formation of an irreverently ecopolitical subject. 
Ensino, Saúde e Ambiente - Número Especial, pp. 44-88, Junho. 2020

Não junto minha voz à dos que, falando em paz, pedem aos oprimidos, aos esfarrapados do mundo, a sua resignação. Minha voz tem outra semântica, tem outra música. Falo da resistência, da indignação, da 'justa ira' dos traídos e dos enganados. Do seu direito e do seu dever de rebelar-se contra as transgressões éticas de que são vítimas cada vez mais sofridas

Paulo Freire (1996)

\section{Prólogo: a nova realidade ecopolítica da luta ambiental no Brasil}

Observando o campo social da Educação Ambiental pela perspectiva teórica dos aparelhos ideológicos de Estado de Althusser (1970), da noção de Hegemonia de Gramsci e dos mecanismos ideológicos de reprodução social de Bourdieu e Passeron (1992), abordando os conceitos de Drama Social (TURNER, 1982), antiecologismo (LAYRARGUES, 2017, 2018a), sujeito ecológico (CARVALHO, 2004), armadilha paradigmática (GUIMARÃES, 2006); e adotando, por fim, a perspectiva da Pedagogia da Indignação de Paulo Freire (2000) como horizonte estruturante desta reflexão, nosso objetivo com este ensaio é o de trazer algumas leituras interpretativas da conjuntura ecopolítica nacional - demarcada pelo retrocesso ambiental -, combinada com a conjuntura global do colapso climático, no marco histórico dos primeiros seis meses do governo Bolsonaro, regime político declaradamente pautado pelo signo do antiecologismo e pela crença negacionista climática.

Com esses subsídios conjunturais em mãos, nosso propósito é de refletir em que medida essa conjuntura interage com o contexto sociopolítico no campo da Educação Ambiental. A questão do debate gira em torno de saber se e como essa nova realidade ecopolítica desafia a capacidade de atualização da educação ambiental brasileira para fazer frente adequadamente e reagir à altura da nova conjuntura de intensificação da luta ambiental democrática contra políticas ecocidas. O horizonte aqui é o de compreender sob quais condições a Educação Ambiental poderá ser afetada e modificada ante o traumático, intenso e multifacetado drama social ecopolítico brasileiro, drama social que comporta simultaneamente o risco da estagnação seguindo conformando um sujeito ecológico conservador e a oportunidade da mudança para a formação de um sujeito irreverentemente ecopolítico.

$\mathrm{O}$ argumento que pretendemos desenvolver neste ensaio parte do pressuposto de que as relações de poder na sociedade de classe são assimétricas e desiguais, e que envolvem mecanismos variados de opressão simbólica e dominação cultural, que se valem de estratégias sutis manipulação ideológica da subjetividade do sujeito, para fins de controle e manutenção 
Ensino, Saúde e Ambiente - Número Especial, pp. 44-88, Junho. 2020

da ordem social capitalista estabelecida. A tarefa de neutralizar a justa ira dos oprimidos demanda um intenso trabalho de convencimento ideológico, a partir da imposição da pedagogia da ordem e da obediência, que ecoa desapercebida pelos poros mais íntimos do corpo societário, forjando um imaginário servil e subserviente ao interesse do capital, resignado a seu papel de pequenas adaptações individuais na esfera privada.

$\mathrm{O}$ argumento que aqui apresentamos é o de que a Educação Ambiental brasileira se inscreve nessa lógica. Ao curso dos anos, ela teria sofrido uma inflexão nas suas intencionalidades pedagógicas e atualmente se encontra totalmente domesticada pelo currículo oculto do ambientalismo de mercado. Aparelhada ideologicamente, tornou-se um modelo conservador e reformista de Educação subserviente ao sistema; mas é justamente ante o trágico quadro dos múltiplos prismas do drama social ecopolítico que impôs uma nova realidade para a luta ecológica brasileira, que se encontra a semente da transmutação dos horizontes formativos da Educação Ambiental. O tempo presente demanda uma repactuação dos sentidos que se pretende imprimir daqui em diante; mas ao mesmo, é exatamente esse mesmo tempo que oferece as bases para esta necessária repactuação do que se espera como efeitos últimos da Educação Ambiental.

\section{A anomalia da semana do meio ambiente de 2019: nada a comemorar}

A semana do meio ambiente, tradicionalmente celebrada em torno do dia 5 de junho, é uma data comemorativa anual que evoca a reflexão sobre o progresso da pauta ambiental desde a Conferência de Estocolmo, em 1972. É uma data simbólica especial que lembra à sociedade a importância da proteção ambiental, e serve como um momento de reflexão e conscientização sobre a questão ambiental.

Contudo, mal completados seis meses do regime Bolsonaro no poder, a palavra de ordem que predominou ao longo da semana do meio ambiente no ano de 2019, foi "nada a comemorar".

Em tom de protesto nas diversas manifestações públicas, essa parece ter sido a tônica que surpreendentemente imperou no campo ambiental brasileiro. As avaliações dos especialistas, para lá de pessimistas, acusavam estar em curso um severo desmonte ambiental, corroendo a estrutura político-administrativa da gestão ambiental federal por dentro do próprio governo. Um ataque sistemático e sem precedentes contra as instituições públicas de proteção ambiental, que precisava ser veementemente denunciado e combatido pelos 
Ensino, Saúde e Ambiente - Número Especial, pp. 44-88, Junho. 2020

movimentos ecologistas, para evitar a eminente implosão dos instrumentos de gestão ambiental pública pelo próprio governo executivo federal.

De fato, não havia motivo para se comemorar a semana do meio ambiente naquele ano de 2019 no Brasil. Muito pelo contrário, não faltaram razões para se lamentar, com a abrupta e profunda mudança de rumo na pauta ambiental no governo federal, desde que se iniciou há praticamente cinco décadas atrás, o longo processo de institucionalização pública da defesa ambiental no país. Desde o regime militar, com a criação da Secretaria Especial do Meio Ambiente em 1973, a instância político-administrativa federal que precedeu o Ministério do Meio Ambiente; e com a instituição da Política Nacional do Meio Ambiente em 1981, de onde todo arcabouço da gestão e legislação ambiental despontaria; essa foi a primeira vez que a sociedade brasileira se viu diante de um governo - novamente militar - que adotou uma enfática narrativa conspiratória que explicitamente afirmava que a política ambiental brasileira havia sido manipulada por 'esquerdistas' infiltrados no campo ambiental, cuja meta residiria na sabotagem da economia brasileira, se a defesa ambiental fosse bem sucedida. $\mathrm{O}$ regime Bolsonaro inicia sua gestão com o firme propósito de destravar o crescimento econômico eliminando as restrições ambientais, impostas especialmente aos ruralistas, madeireiros e garimpeiros.

Naqueles agonizantes primeiros seis meses do regime Bolsonaro, a lista de acontecimentos acerca da desativação institucional da política ambiental brasileira já era longa o suficiente para se perceber com clareza que o Brasil havia entrado vertiginosamente na contramão da história. Não havia margem de dúvidas que o país estava inacreditavelmente diante de um devastador tsunami de retrocessos ambientais, caminhando na direção da virtual extinção dos instrumentos públicos de proteção ambiental na esfera federal, regido pelo signo do antiecologismo ${ }^{1}$ que invadiu o Estado nacional brasileiro como plano de governo.

Apresentada oficialmente à opinião pública como entrave ao pleno desenvolvimento econômico do país, fruto de um radicalismo exagerado ecologista, a política ambiental brasileira, demonizada; seria definitiva e corajosamente eliminada, para enfim destravar o ambiente de negócios, sufocado por todos os obstáculos da defesa ambiental.

A sustentação narrativa que alicerçou essa ruptura institucional argumentava que a política ambiental brasileira estava completamente impregnada pela agenda ideológica da 'esquerda' que teria se infiltrado na trincheira do movimento ambiental, cujo interesse perverso e oculto seria o de sabotar a soberania e a economia brasileira. Nessa formulação narrativa conspiratória, a bandeira ambiental teria sido apropriada por interesses ideológicos

\footnotetext{
${ }^{1}$ Para um aprofundamento conceitual sobre o signo do antiecologismo, ver: Layrargues (2017, 2018 a).
} 
escusos que visariam restringir ou impedir o acesso aos recursos naturais, bloqueando a geração de riqueza econômica no Brasil: para a comunidade ambiental, toda aquela riqueza natural contida nas unidades de conservação, nas terras indígenas e nas áreas de preservação permanente e de reserva legal nas propriedades privadas, que em tese poderia tornar o país uma superpotência econômica, deveria ser mantida intocada. Nem de longe a narrativa justificadora dessa ruptura institucional passou pelo argumento da tentativa de se reequilibrar a tensão entre o desenvolvimentismo e a sustentabilidade, onde a proteção ambiental teria sido rigorosa demais, e que havia então chegado a hora de se reestabelecer um equilíbrio justo entre economia e ecologia.

As obras de Carrasco (2006), de Orleans e Bragança (2012) e de Delingpole (2012), oferecem a sustentação argumentativa desta pueril teoria conspiratória de matriz antiecologista, que alcançou a presidência da república e amparou o discurso presidencial, na medida que Bolsonaro reafirmou seguidamente que iria retirar o 'viés ecológico' da política ambiental brasileira $^{2}$. Os autores, todos negacionistas climáticos, encaram o movimento ambiental como sendo uma espécie de 'cavalo de Tróia' que esconderia internamente interesses ideológicos ocultos: por trás da aparência altruísta da proteção da natureza, que aparentaria apenas a preocupação desinteressada com a preservação da Vida no planeta Terra; estaria o controle geopolítico de nações interessadas em limitar ou impedir o desenvolvimento capitalista do país. Não por acaso, o rótulo depreciativo de 'melancias'; verdes por fora e vermelhos por dentro, seria a nova classe dos fanáticos mais interessados em destruir o sistema capitalista do que em salvar o planeta da crise ambiental, querendo com isso afirmar que o movimento ambiental seria descarada e cinicamente esquerdista, quando afirmam que o problema ambiental é o capitalismo. Dando nome aos bois, e reconhecendo-se o alinhamento narrativo com essa literatura, Bolsonaro inclusive afirmou que o Brasil era alvo de uma 'psicose ambientalista', ${ }^{3}$ exatamente o título do livro do conservador porta-voz da família imperial brasileira, Dom Bertrand de Orleans e Bragança, com uma horda de 'ongueiros de esquerda' ideologicamente comprometidos em denegrir a imagem do agronegócio brasileiro perante o mercado externo e a comunidade internacional ${ }^{4}$.

Bolsonaro deu nome e sobrenome aos ecologistas 'radicais' de 'esquerda', empenhados na vil sabotagem da soberania e economia brasileira: os ativistas ecologistas militantes das ONGs, os povos indígenas, quilombolas e os servidores públicos federais da

\footnotetext{
${ }^{2}$ https://www.oantagonista.com/brasil/ideia-e-tirar-o-vies-ideologico-que-o-setor-ambiental-ficou-associado/

3 https://oglobo.globo.com/mundo/bolsonaro-diz-ter-falado-que-brasil-alvo-de-psicose-ambientalista-paramerkel-23773590

${ }^{4}$ https://www.terra.com.br/noticias/brasil/ongs-rebatem-fala-de-bolsonaro-sobrequeimadas,9f6096e641ac509c6b4ca51fcb3877cf4shslz89.html
} 
Ensino, Saúde e Ambiente - Número Especial, pp. 44-88, Junho. 2020

carreira ambiental, onde estes últimos teriam se infiltrado no Estado para ali criar uma política ambiental impeditiva ao florescimento da economia primária e subserviente aos interesses externos ferindo a soberania brasileira.

Ao longo de sua inexpressiva e insossa trajetória no baixo clero parlamentar, Bolsonaro já havia deixado claro que não manifestava qualquer simpatia à causa ambiental. Ao contrário, apresentava fixação por atividades econômicas extrativas como a pesca e a mineração, e enaltecia o pujante e lucrativo agronegócio ruralista brasileiro, que estaria sendo vitimado por uma suposta 'indústria de multas' que atrapalharia os negócios do empresário do campo. Mas o sinal de alerta no movimento ambiental soou quando, o então candidato à presidência da república ainda em campanha eleitoral, afirmou despudoradamente que pretendia extinguir o Ministério do Meio Ambiente, caso eleito presidente.

Ali as intenções até então veladas do novo governo deram corpo à grande ausência que não passou desapercebida ao longo do período eleitoral em 2018: a total inexistência de propostas para a pauta ambiental dentro do programa de governo do candidato do PSL. Se naquele momento ainda não era possível antever claramente o que isso poderia significar e qual impacto teria na política nacional do meio ambiente; ao afirmar sua intenção de acabar com o Ministério do Meio Ambiente, ficou comprovado que a intenção do governo Bolsonaro com relação à agenda ambiental era o seu completo desmonte. O "Caminho da Prosperidade", para Bolsonaro, definitivamente não passava pelo desenvolvimento sustentável.

Esse episódio representou o início do drama social (TURNER, 1982) do desmonte institucional, a partir do qual a comunidade ambiental percebeu que poderia esperar pelo pior quanto aos rumos da política ambiental na gestão Bolsonaro. Pretender extinguir um ministério do meio ambiente não significa uma mera e trivial reforma político-administrativa de um novo governo submetido ao rigoroso ajuste neoliberal; é uma política pública escancarada e radicalmente antiecologista. Era uma ruptura histórica que precisaria ser combatida.

Não era um simples esforço neoliberal de redução do Estado, mas a total desresponsabilização do Estado na garantia constitucional da defesa do meio ambiente. A garantia constitucional da incumbência do poder público defender as condições ambientais íntegras simplesmente estava em jogo. O Estado, ao se ausentar de suas responsabilidades na garantia do meio ambiente ecologicamente equilibrado, afrontou a Constituição. Inacreditavelmente o país se viu diante da possibilidade de se perder todas as referências legais e institucionais historicamente construídas para assegurar minimamente a defesa ambiental. A ameaça de fechar o Ministério do Meio Ambiente explica a incógnita da 
Ensino, Saúde e Ambiente - Número Especial, pp. 44-88, Junho. 2020

ausência de propostas do programa de governo de Bolsonaro para a agenda ambiental: era apenas uma opção covarde de omitir a real intenção de se radicalizar a desregulação ambiental pública, que já vinha a passos largos no governo Temer, concluindo-se no regime Bolsonaro.

Eleito, afirmando que iria acabar com a 'briga' da área ambiental com a pasta da agricultura, e que perseguiria os militantes da esquerda ambientalista dentro do sistema federal do meio ambiente; Bolsonaro quebra a lógica da indicação de nomes técnicos de reconhecida competência na área ambiental, e nomeia justamente um representante do agronegócio patronal para assumir o cargo de ministro do meio ambiente, o controverso Ricardo Salles, que já acumulava em seu currículo uma condenação judicial por fraude ambiental. Dali em diante, o sistemático e radical desmonte do aparato ambiental público federal entrou em ação.

Pela primeira vez na história do ambientalismo no Brasil, e com razão, não havia motivo para se comemorar o dia do meio ambiente. Havia motivos, de sobra, para se indignar e protestar; porque agora, a luta ecologista não se resumia mais à defesa da natureza e da qualidade ambiental.

O drama social do ataque institucional impondo o retrocesso ambiental forçou a luta ecologista a se transmutar para além da defesa da natureza propriamente dita, passando a envolver também a defesa das instituições públicas federais que asseguravam a qualidade ambiental. Como se não bastasse o monumental esforço da gestão ambiental pública, com a colaboração do movimento socioambiental, na linha de frente da luta ambiental, para assegurar boas condições ecológicas dos biomas brasileiros em áreas de proteção ambiental, para combater a grilagem e invasão de terras públicas, o desmatamento e as queimadas, para licenciar atividades potencialmente poluidoras, entre outras ações de campo no território, agora a luta ecologista precisou agregar outra inesperada frente de batalha, agora no campo institucional. Além da fauna, flora, biomas e ativistas defensores da natureza ameaçados, instituições e servidores públicos também ingressaram no repertório das ameaças contra a defesa ambiental.

A feroz e sistemática investida antiecologista às institucionalidades governamentais de defesa ambiental demarcou a nova realidade do ecologismo brasileiro a partir de 2019, obrigando-o a reconfigurar a sua pauta programática, trazendo à ordem do dia, a mobilização popular atuante na vida política, com movimentos coletivos de protesto e contestação para denunciar e combater a orientação antiecologista do novo governo, nas ruas. Em certa medida, o retrocesso implicou na recuperação do espírito subversivo do ecologismo datado 
Ensino, Saúde e Ambiente - Número Especial, pp. 44-88, Junho. 2020

dos anos 60, quando sua agenda predominante se pautava pela denúncia e protesto público da insustentabilidade do desenvolvimento economicista, nas ruas. Afinal, em certa medida, o retrocesso reativou a pedagogia da indignação, demarcando as consequências dessa nova realidade no campo da luta ambiental.

\section{A Pedagogia da Indignação e a esperança do protesto contra o retrocesso ambiental}

E foi partindo exatamente desse contexto, que uma destacada expoente do ambientalismo brasileiro, Samyra Crespo, publicou uma reflexão no site da Agência Envolverde ${ }^{5}$, questionando a ênfase que a comunidade socioambiental teria dado à narrativa catastrofista com notícias apocalípticas sobre o colapso ambiental, "apavorando as pessoas e apontando a vilania humana", na semana do meio ambiente.

Reconhecendo que a palavra de ordem 'nada a comemorar' ganhou destaque nos noticiários e redes sociais na semana do meio ambiente de 2019, a autora condenou exatamente aquilo que foi o ânimo fulcral dos protestos públicos ocorridos em várias cidades brasileiras com manifestações em defesa das instituições ambientais públicas e para estancar o vertiginoso avanço dos retrocessos socioambientais. No artigo, Crespo correlacionou essa palavra de ordem 'nada a comemorar' com uma narrativa desesperada, aflita, angustiante; correlacionou o protesto contra o retrocesso ambiental como sendo uma narrativa sombria que representaria uma pedagogia do medo que rouba o lugar da esperança, o que poderia gerar apatia, desalento, paralisia.

O grito de ordem 'nada a comemorar' na semana do meio ambiente não foi algo despropositado ou exagerado. Foi bastante fiel à leitura da conjuntura socioambiental contemporânea, na medida que a luta ambiental sofreu uma inflexão na sua trajetória histórica com a quebra do pacto da sustentabilidade como orientação ao desenvolvimentismo. Ou seja, não foi um alarme falso alardeando um problema superdimensionado por neuróticos desesperados que teria sombreado o lugar das comemorações dos avanços em direção à sustentabilidade. Foi o infeliz e indesejado retrato de uma época singular, que destoa profundamente de todo histórico da semana de comemorações do meio ambiente, que contava com espaço para o protesto ecologista contra os riscos das tentativas de retrocessos ambientais, mas em uma proporção muito menos aguda.

\footnotetext{
${ }^{5}$ https://envolverde.cartacapital.com.br/entre-aflitos-e-apocalipticos-e-preciso-afirmar-o-valor-da-vida-dobelo-e-da-esperanca/
} 
Ensino, Saúde e Ambiente - Número Especial, pp. 44-88, Junho. 2020

No ano de 2019, realmente não havia condições na conjuntura brasileira de se afirmar o valor da vida, do belo e da esperança na semana do meio ambiente, sem ao mesmo tempo denunciar veementemente o desmonte ambiental que ameaçava os instrumentos públicos de proteção da qualidade ambiental. Não havia lugar, como desejava Samyra Crespo, para o predomínio da mensagem de celebração do crescimento da alimentação orgânica, das florestas plantadas, dos jardins de chuva, das tecnologias sustentáveis; afinal, o desmonte ambiental não é facilmente reconhecível à primeira vista pela opinião pública, e a semana do meio ambiente representa uma preciosa janela política de se fazer ouvir minimamente pela oportunidade midiática que a marca comemorativa permite acontecer, para que fosse possível dimensionar junto à sociedade, a profunda gravidade da nova realidade da luta ambiental no país.

Não parece de todo sensato correlacionar a palavra de ordem 'nada a comemorar' única e diretamente com apatia ou desesperança, como se necessariamente o protesto fosse perigosamente vinculado a essa paralisante pedagogia do medo. Com o grito de 'nada a comemorar', vários coletivos e organizações ecologistas foram às ruas manifestar sua indignação e recusa com o retrocesso ambiental. Ali, nas ruas, não se viu desalento ou apatia; ao contrário, se viu justamente a esperança freireana de atuar e intervir politicamente no mundo. De denunciar o mundo que não queremos e cujo curso precisa ser imediatamente interrompido. $\mathrm{O}$ protesto não é indiferença, é a reação apaixonada frente a uma situação limite intolerável. O estranho aqui seria justamente seguir a rotina das comemorações ressaltando as conquistas ambientais de natureza comportamental ou tecnológica, como se o tempo histórico da consolidação definitiva do ambientalismo na sociedade brasileira tivesse permanecido exatamente o mesmo.

Partindo do olhar freireano, há que se considerar sobre a dialética entre a combinação do anúncio com a denúncia. Em sintonia com a Pedagogia da Indignação, Freire (2000) afirmava que não era possível dissociar o anúncio da denúncia, que ambos deveriam ocorrer simultaneamente.

Há que se anunciar os modos de vida sustentáveis e denunciar os modos de vida insustáveis. Há que se defender o caminho da sustentabilidade, mas ao mesmo tempo, combater o da insustentabilidade. Não basta apenas anunciar o caminho da sustentabilidade e acreditar que isso seja suficiente para motivar a conversão ideológica daquele Outro que segue convicto crendo que o caminho da insustentabilidade não se cruza com o caminho da prosperidade, supondo que bastaria a supressão da ignorância - e não da ganância também -, para se pôr um fim à degradação e ao crime ambiental. O antagônico da sustentabilidade não 
Ensino, Saúde e Ambiente - Número Especial, pp. 44-88, Junho. 2020

pode ser desprezado ou ignorado, posto que ele não é resultado da ignorância ecológica, mas sim da ganância econômica; e essa é a raiz da tensão antagônica que rivaliza o poder entre economia e ecologia, entre desenvolvimentismo e sustentabilidade e, em grande medida, entre capital e trabalho. A fraca sustentabilidade do desenvolvimentismo brasileiro não é fruto única e exclusivamente da ignorância ecológica, mas fundamentalmente, da ganância econômica.

Não adianta apenas trabalhar pela regeneração da Vida sem ao mesmo tempo militar contra a destruição da Vida. Mutirões de limpeza, boicote aos canudinhos plásticos, plantios agroflorestais, painéis solares, carros híbridos, soluções tecnológicas e ações individuais positivas que nos aproximam da sustentabilidade são fundamentais, mas não são garantia alguma de uma mudança societária definitiva, exclusivamente guiada pela ética da sustentabilidade ou pelo simples bom senso de sobrevivência.

É preciso sim reciclar e reutilizar os bens de produção além de reduzir e repensar o consumo para se combater a prática do desperdício dos recursos naturais; mas é preciso também combater a lógica do desperdício, configurada pela obsolescência planejada incrustada nos planos de negócios empresariais da economia capitalista, porque é inútil acreditar que seja possível alterar o padrão de consumo sem se alterar também o padrão de produção. Se é a produção quem determina o consumo na economia capitalista, toda e qualquer ação pela sustentabilidade inevitavelmente precisa questionar o modo de produção capitalista.

Não basta aderir ao consumo de produtos orgânicos e tentar consumir produtos livres de agrotóxicos sem concomitantemente se opor ao agronegócio ruralista exportador de commodities, lutar pela reforma agrária e combater a liberação desenfreada de agrotóxicos pelo governo. Não basta abolir o consumo de carne da dieta pessoal sem ao mesmo tempo militar contra a expansão ilegal da pecuária Amazônia adentro. Não basta anunciar e valorizar a sócio e biodiversidade do Cerrado, para estancar o aceleradíssimo processo de conversão do bioma em celeiro mundial de plantio de grãos, sem também denunciar o Estado brasileiro que destinou como política pública para o Centro-Oeste o território ideal da sojicultura, a exemplo da região do MATOPIBA, considerada a última fronteira inexplorada do Cerrado que ao longo da década dos 2020 sofreu uma conversão sem precedentes, processo esse orientado por políticas públicas federais: isso porque a lógica predatória do setor produtivo primário latifundiário e orientado pelo livre mercado seguirá implacavelmente determinada pelo papel geopolítico que o país representa na periferia do sistema capitalista, como mero provedor de commodities naturais vendidas a baixo custo na economia globalizada. 
Ensino, Saúde e Ambiente - Número Especial, pp. 44-88, Junho. 2020

Enfim, o que ocorreu na semana do meio ambiente de 2019 na conjuntura do Brasil, com a palavra de ordem carregada de protesto por não se ter 'nada a comemorar' e que esteve em total sintonia com a crítica à radicalização do retrocesso ambiental, foi justamente a quebra da prevalência da narrativa da esperança do anúncio da sustentabilidade sem a denúncia contra a insustentabilidade. Efeito direto do drama social do pacto com a sustentabilidade rompido pelo desenvolvimentismo desgovernado pelo governo federal, a pedagogia da indignação trouxe à vida o protesto coletivo em massivas manifestações públicas, exercitando o protesto nas ruas como uma nova atitude que se tornou necessária se praticar em nome da defesa do meio ambiente.

Mas chama atenção o fato de pela primeira vez na história da comemoração da semana do meio ambiente, justamente quando o país mergulhou na radicalização do retrocesso ambiental, que a denúncia da insustentabilidade tenha sido condenada, porque o protesto público sombreou o anúncio da sustentabilidade, tido como a referência moral fonte de inspiração que deveria predominar. Há uma certa censura no ar contra o perfil ecologista que entende que a construção da sustentabilidade não se faz apenas com o seu anúncio, mas também com a denúncia da insustentabilidade, por meio da militância política. " $O$ que fizemos com a esperança? Porque não promover o amor em vez da dor? (...) Fica o alerta: sejamos os arautos da esperança que vivifica e não os coveiros de um mundo que agoniza", como finaliza o texto de Samyra Crespo, é uma narrativa ideológica que apresenta o ethos ecologista que atua politicamente combatendo as forças da insustentabilidade de modo sutilmente depreciativo, por ter se desviado do papel social do anúncio (da esperança) da sustentabilidade. A mensagem é clara: neste modelo, não há lugar para a denúncia, apenas o anúncio; e não a combinação freireana do anúncio conjugado com a denúncia.

\section{O recado da rebeldia com a causa do protesto de Greta Thunberg}

Enquanto o Brasil se encaminhava para a conclusão das eleições presidenciais no final de 2018, uma foto correu o mundo e ganhou as manchetes. Era de uma jovem adolescente, sentada no chão em uma calçada, cabisbaixa e encostada em uma fria parede de um prédio, com um cartaz ao seu lado. Se estivesse nas ruas de São Paulo, teria sido facilmente confundida com uma sem-teto desempregada pedindo esmola, entre tantos outros moradores de rua nas grandes cidades brasileiras. Mas ela não estava no Brasil, e não estava pedindo esmola. Ela estava na Suécia, e estava fazendo um protesto. Uma solitária e inusitada greve estudantil pelo clima, que rapidamente se tornou um símbolo e uma referência mundial que 
Ensino, Saúde e Ambiente - Número Especial, pp. 44-88, Junho. 2020

passou a inspirar a juventude pelo mundo afora, revitalizando o movimento de massas, criando a partir daí o emblemático Friday for Future.

Para manifestar seu descontentamento e protestar contra a passividade do governo sueco em relação ao enfrentamento das mudanças climáticas, Greta recorreu à rebeldia da desobediência civil afrontando seu dever enquanto estudante: deixou de ir às aulas entre final de agosto e início de setembro, trocando a cadeira da escola pela calçada em frente ao prédio do parlamento em Estocolmo.

Como ainda não podia votar, a única forma de se manifestar e intervir politicamente no mundo foi por meio do protesto público, justificando a escolha pelo corajoso ato de desobediência civil. "Senti que não havia sentido em ir à escola se não houvesse futuro", afirmou em entrevista à revista Time ${ }^{6}$.

Passadas as eleições na Suécia, Greta manteve o protesto solitário por todas as sextasfeiras, dia da semana que as aulas terminam mais cedo. E o recado era muito simples: repreender as lideranças políticas e reivindicar dos governantes suecos ações consequentes definitivas para frear as mudanças climáticas. Greta não queria aumentar a conscientização pública sobre a crise climática. Seu protesto era especialmente direcionado a um destinatário específico, e tinha um propósito muito claro: Greta queria que os líderes políticos da Suécia levassem realmente a sério o Acordo de Paris. Greta queria pressionar o governo do seu país a assumir a sua responsabilidade de Estado para implementar políticas públicas efetivas e pautadas pela urgente transição rumo à economia de baixo carbono.

Desde que começou a se preocupar com o assunto das mudanças climáticas, ainda com nove anos de idade, Greta se tornou vegetariana e adotou o consumo sustentável, negando-se a comprar qualquer coisa que não fosse absolutamente necessária, e permaneceu vigilante às suas emissões de carbono. Adotou um estilo de vida com o menor impacto ambiental possível, sua família instalou painéis solares na residência, plantou sua própria horta e o carro - elétrico - só sai da garagem quando é indispensável, porque o meio de transporte cotidiano é a bicicleta. Hábitos individuais e domésticos exemplares, pra lá de ecologicamente corretos, o tipo-ideal perfeito de um sujeito ecológico que adaptou seu comportamento para oferecer a sua cota de contribuição individual esperada na transição à sustentabilidade.

Mas Greta entrou em depressão com essa pedagogia do medo proveniente do trauma do colapso climático imediato que se abateria exatamente sobre a sua geração; e só conseguiu sair da apatia quando entendeu que frente ao colapso climático, esse modelo padrão do sujeito

\footnotetext{
${ }^{6}$ https://www.dn.pt/lusa/interior/frases-clima-principais-frases-da-ativista-sueca-greta-thunberg10926937.html
} 
Ensino, Saúde e Ambiente - Número Especial, pp. 44-88, Junho. 2020

ecológico ${ }^{7}$ orientado pela máxima liberal de 'cada um fazer a sua parte', com a adoção de boas práticas e comportamentos ambientais individuais; tinha chegado ao seu limite. Agora a gravidade da situação exigia uma solução de outra natureza. Ante o cenário palpável do colapso climático global, uma nova resposta foi gestada.

Quando compreendeu que a desesperança era derivada da impotência da ação individual conformada à esfera privada, Greta rompeu o paradigma e foi além do esperado para o papel a ser desempenhado por um sujeito ecológico civilizadamente orientado pela sustentabilidade, com a criação desse solitário movimento subversivo de desobediência civil, ao faltar as aulas para no seu lugar realizar um ato político de contestação contra o governo de seu país. E em pouco tempo de ativismo, com o protesto agora direcionado aos dirigentes do establishment - a elite político econômica mundial -, Greta inovou e saiu completamente do lugar comum para se firmar como uma ativista ambiental militante na vida pública e no âmbito internacional, muito além da consumidora ecologicamente consciente que adaptou seus comportamentos na esfera privada e doméstica. Inesperadamente contrariou os poderes estabelecidos, e enquadrou os donos do poder global a finalmente assumirem a responsabilidade que lhes cabe no enfrentamento da crise climática, condizente com sua decisiva influência na tomada de decisão sobre as políticas globais, enquanto lideranças das maiores potências políticas e econômicas do setor público e privado mundial.

Greta, talvez pela condição de autista, percebeu que a clássica fórmula de cada um de nós individualmente fazer a sua parte, comportadamente na esfera privada; e contar passiva e esperançosamente com a conversão do restante da humanidade desconsiderando as relações de poder na política, havia se esgotado. Chegou ao seu limite e partiu ao ataque: agora é tempo de se revoltar, "É hora de ficar com raiva", em suas próprias palavras", superando assim o imaginário domesticado deste modelo padrão hegemônico do sujeito ecológico, convertendo-o em um sujeito ecopolítico. Para recuperar o curso civilizatório que progressivamente vinha reconhecendo a importância da natureza selvagem, foi preciso recorrer à selvageria humana.

A conjuntura ambiental global, agora dramática com a aproximação a passos largos do colapso ambiental, exigiu uma resposta à altura do desafio. E Greta demonstrou total

\footnotetext{
${ }^{7}$ Carvalho (2004) define da seguinte forma o sujeito ecológico: "Esse modo ideal de ser e viver orientado pelos princípios do ideário ecológico é o que chamamos de sujeito ecológico. O sujeito ecológico é um ideal de ser que condensa a utopia de uma existência ecológica plena, o que também implica uma sociedade plenamente ecológica. $O$ ideal de ser e de viver em um mundo ecológico se vai constituindo como um parâmetro orientador das decisões e escolhas de vida que os ecologistas, os educadores ambientais e as pessoas que aderem a esses ideais vão assumindo $e$ incorporando, buscando experimentar em suas vidas cotidianas essas atitudes $e$ comportamentos ecologicamente orientados". (p. 65)

${ }^{8}$ https://www.straitstimes.com/world/time-to-get-angry-teen-climate-activist-says-in-davos
} 
Ensino, Saúde e Ambiente - Número Especial, pp. 44-88, Junho. 2020

afinidade com o diagnóstico catastrofista das mudanças climáticas, percebeu a urgência do tempo presente que é outro, bem diferente do passado recente quando só se anunciava a vizinhança de uma crise ambiental num futuro em breve. Greta pertence à geração que finalmente será diretamente impactada pelo colapso climático, e isso se tornou simplesmente inaceitável. Por se colocar esta geração em xeque, estava dado o choque geracional. Adultos e jovens sofreram a primeira cisão geracional da história, porque os adultos, especialmente aqueles que se colocam como decisores políticos, falharam em deixar um planeta saudável como herança aos respectivos filhos. Por isso Greta qualificou a crise ambiental como uma situação de emergência sem precedentes, e que precisaria ser enfrentada com urgência, porque ela representa uma ameaça concreta ao futuro dos jovens:

"Eu só cheguei na hora certa. Cada vez mais pessoas têm consciência da situação de emergência em que vivemos, do fato de que estamos atravessando uma crise existencial que não foi nunca abordada dessa forma".

"Como devo me sentir segura quando sei que estamos diante da crise mais aguda da história da humanidade? Quando sei que, se não agirmos agora, tudo logo será tarde demais? A primeira vez que ouvi sobre o aquecimento global, pensei: isso não pode estar certo, de jeito nenhum, há algo sério o suficiente para ameaçar nossa própria existência". ${ }^{10}$

"Somos só crianças que protestam. Não deveríamos estar fazendo isso, não deveríamos ter que fazer, sentir que nosso futuro está ameaçado a ponto de termos que faltar às aulas para lutar. É um fracasso das gerações anteriores" $" 11$.

Reverberando essa narrativa catastrofista do caos climático, Greta encarna o espírito dos 'profetas do apocalipse', apavorando as pessoas com a aproximação do fim do mundo e apontando a vilania humana responsável pelo colapso climático. Mas essa nova profeta do apocalipse não possui rugas da idade avançada no seu rosto, ao contrário, guarda os traços da infância, consciente de que é o seu futuro que precisa ser defendido, sem tempo a perder. E por isso, torna-se autora de um discurso competente e se constitui como uma legítima liderança política que de súbito passou a representar a juventude planetária.

\footnotetext{
${ }^{9}$ https://brasil.elpais.com/brasil/2019/03/09/actualidad/1552146532 090042.html

${ }^{10}$ https://eco21.eco.br/eu-quero-me-sentirsegura/?fbclid=IwAR1QxIKqZmeCaXJe5jA0V50J6c3vNYJf2Ycmq83 pwKt4qqR4mZw 0SO 04

${ }^{11}$ https://istoe.com.br/greta-quer-salvar-o-futuro/
} 
Ensino, Saúde e Ambiente - Número Especial, pp. 44-88, Junho. 2020

Esse sujeito ecopolítico rebelde chamou a atenção. O ineditismo da reação inusitada de uma jovem adolescente indignada com a omissão dos adultos no governo, insensatos com relação ao enfrentamento das mudanças climáticas, conquistou os holofotes da mídia, e em pouco tempo, Greta se tornou uma pequena grande celebridade com presença garantida em eventos globais com tomadores de decisão acerca das questões climáticas. No Fórum Econômico em Davos em 2019, cansada de ouvir as falsas promessas de esperança de um futuro melhor, Greta manifestou sua compreensão acerca da pedagogia do medo, ao assumir a narrativa catastrofista de um planeta que agoniza, e que seria exatamente essa a perspectiva de urgência que deveria ativar a mobilização social convocando o engajamento militante em uma ação coerente com o drama climático:

"Os adultos ficam dizendo: devemos dar esperança aos jovens. Mas eu não quero a sua esperança. Eu não quero que vocês estejam esperançosos. Eu quero que vocês estejam em pânico. Quero que vocês sintam o medo que eu sinto todos os dias. E eu quero que vocês ajam. Quero que ajam como agiriam em uma crise. Quero que vocês ajam como se a casa estivesse pegando fogo, porque estâ". ${ }^{12}$

"Se é preciso parar as emissões que provocam as alterações climáticas, então é para parar já. (...) Não compreendo como continuam a viver como se não fosse nada. Há 30 anos que nos dizem para sermos positivos. Desculpem, mas não vou por aí. Não resulta, ou já teríamos baixado as emissões de gases tóxicos para o planeta. O que precisamos é ação". ${ }^{13}$

Em manifestação pública da juventude alemã realizada no dia 29 de março de 2009 nas ruas de Berlim, Greta critica a indiferença e a passividade das pessoas ante a nova realidade global que deveria ser compreendida por todos como dramática, uma situação extraordinária que surpreendentemente ainda não despertou as pessoas do torpor da anestesiante rotina cotidiana:

\footnotetext{
${ }^{12}$ https://g1.globo.com/educacao/noticia/2019/03/15/poucos-adultos-estao-escutando-diz-adolescenteindicada-ao-nobel-que-criou-uma-greve-global-pelo-clima.ghtml

${ }^{13} \mathrm{http}: / /$ visao.sapo.pt/actualidade/mundo/2019-01-28-Quem-e-Greta-Thunberg-a-adolescente-sueca-queagitou-Davos-
} 
Ensino, Saúde e Ambiente - Número Especial, pp. 44-88, Junho. 2020

"Devemos entrar em pânico e, em pânico, não estou a falar de gritar de pânico, quero dizer sair de nossas zonas de conforto, porque quando se está em crise, muda-se o comportamento". ${ }^{14}$

Ainda em Davos, Greta sinalizou que o problema a lidar com as questões climáticas não é exatamente a ignorância ambiental das pessoas comuns, mas a ganância da elite político-econômica que tem total clareza do que está em jogo e não abre mão de seus interesses na desigual relação de poder; e que portanto, há um enfrentamento político na esfera pública democrática a ser realizado, para além dos gestos pessoais de um cidadão ecologicamente correto. O problema agora não é mais a falta de conscientização sobre a crise ambiental, mas a falta de compromisso e responsabilidade ambiental do mundo político e das lideranças econômicas. O problema não é a fraca disseminação societária da mensagem ecológica, mas a forte determinação antiecologista por parte dos donos do poder político e da riqueza econômica global. Ou seja, não se trata unicamente de um processo de conversão de consciência, mas de enfrentamento político objetivo:

"Algumas pessoas, algumas empresas, alguns tomadores de decisão em particular, sabem exatamente que valores inestimáveis têm sacrificado para continuar a ganhar quantias inimagináveis de dinheiro. E eu acho que muitos de vocês aqui hoje pertencem a esse grupo de pessoas". ${ }^{15}$

Por conta do boicote às aulas, Greta foi taxada por políticos conservadores de subversiva e inconsequente por estar desprezando a escola; ao que replicou com astúcia, afirmando que a greve estudantil tinha como propósito exatamente cuidar do futuro, demarcando publicamente o choque geracional que colocou os adultos no banco dos réus:

"Para que vamos estudar se vocês nos roubaram o futuro?"16

"Para quê estudar para um futuro que talvez nunca aconteça quando ninguém faz nada para o preservar? Agora é o tempo de nos enfurecermos". ${ }^{17}$

\footnotetext{
${ }^{14}$ https://www.dn.pt/lusa/interior/frases-clima-principais-frases-da-ativista-sueca-greta-thunberg10926937.html

${ }^{15}$ https://brasil.elpais.com/brasil/2019/02/27/opinion/1551290093277722.html

16 https://www.cartamaior.com.br/?/Editoria/Historias-do-Futuro/Greta-Thunberg-antes-de-20-deagosto/48/43761

${ }^{17}$ https://www.cartamaior.com.br/?/Editoria/Mae-Terra/Jovens-fazem-greve-pelo-clima/3/43142
} 
Ensino, Saúde e Ambiente - Número Especial, pp. 44-88, Junho. 2020

Estimulados com o protesto de Greta, em novembro de 2018, cerca de quinze mil estudantes australianos boicotaram as aulas para dizer ao governo que deveria combater as mudanças climáticas. Mas o então primeiro-ministro australiano, Scott Morrison reagiu mal, condenando o ativismo dos jovens: "O que queremos nas escolas é mais aprendizagem e menos ativismo". E a juventude australiana respondeu ao ministro com um cartaz nas ruas na manifestação seguinte: "Nós seremos menos ativistas se vocês fizerem menos merda" 18 . E assim, parece que o fenômeno Greta inspirou entre a juventude essa revolução no modelo dominante do perfil do sujeito ecológico ideal, que viu diante do repertório de possibilidades de se agir em prol da defesa ambiental, a potencialidade do ativismo político e da ação coletiva. A contestação política por meio da desobediência civil demarcada pela 'greve' estudantil começou a fazer parte do perfil do sujeito ecológico, que por sua vez, começa a transmutar-se em sujeito ecopolítico.

Em visita ao Vaticano em abril de 2019, Greta foi encorajada pelo papa Francisco, que também engajou-se ética e politicamente na cruzada contra as mudanças climáticas, a seguir com o compromisso: "Vá em frente e que Deus te abençoe"19, aconselhando-a a seguir adiante com sua mobilização pelo clima, liderando todo esse processo de militância política como uma nova forma do agir ecológico.

Não se trata mais aqui de seguir difundindo a mensagem ecológica aos quatro ventos, na expectativa de superar a ignorância sobre o colapso ambiental. Foi-se o tempo em que era necessário centrar esforços educativos na ampliação da conscientização ambiental; para dar lugar agora a uma ênfase educativa na responsabilização de quem carrega o poder de decisão das políticas públicas e dos investimentos privados. Se o colapso climático chegou, é porque a sustentabilidade ainda não estava devidamente encarnada no desenvolvimento a ponto de evitar o desastre a tempo. O legado da Rio-92 com o pacto do desenvolvimento sustentável no primeiro quarto de século desde a Conferência do Rio, foi mais discurso do que prática e não surtiu o efeito desejado da transição ecológica. E assim, havia chegado o momento de efetivamente se cobrar a demonstração do compromisso efetivo da sustentabilidade como realmente orientadora do desenvolvimentismo.

Trata-se agora nesse novo contexto, de protagonizar um perfil adequado do sujeito ecológico atualizado com a nova realidade; aquele que agora também se investe da militância política na esfera pública cobrando responsabilidade do Estado, como mais uma forma importante do eco cidadão contribuir com a construção do caminho da sustentabilidade.

\footnotetext{
${ }^{18}$ https://brasil.elpais.com/brasil/2019/02/27/opinion/1551290093 277722.html

${ }_{19}$ https://www.dn.pt/mundo/interior/papa-falou-com-jovem-ativista-sueca-pelo-clima-e-disse-va-em-frente10807171.html
} 
Ensino, Saúde e Ambiente - Número Especial, pp. 44-88, Junho. 2020

Aquele que além da coerência entre os princípios e os comportamentos ecologicamente éticos, também luta pela defesa ambiental, se coloca como um cidadão manifestamente contrário às forças da insustentabilidade. Não é aquele que apenas incorpora novos comportamentos ecológicos no seu ambiente doméstico ou do trabalho, mas também luta pelos direitos ambientais.

E isso é revolucionário, porque afronta o perfil domesticado do cidadão ecologicamente consciente mas conformado pelo ethos capitalista a não reagir na esfera pública com o poder transformador da ação coletiva; e é subversivo, porque afronta a ordem socioambiental estabelecida.

A novidade aqui é a abertura à fronteira do ativismo político que afronta uma ordem social ecologicamente nociva. E por isso, a legítima cobrança da responsabilidade institucional do governo e das lideranças econômicas, a pressão política por um modelo econômico não ecocida. A legítima cobrança para que se mude o sistema, não o clima.

Importa destacar que Greta, que em praticamente todas as reportagens jornalísticas é qualificada como uma 'ativista ambiental', não abandonou a clássica fórmula do 'cada um fazer a sua parte com pequenas atitudes no dia a dia que podem fazer toda a diferença', mantendo-se indiferente se outros atores sociais investidos de um poder político e econômico desproporcionalmente maior, como o governo e a elite econômica, pouco ou nada fazem pela proteção ambiental; ou pior, caminham obstinadamente na contramão da sustentabilidade. Tanto que por ocasião da Cúpula das Nações Unidas sobre Ação Climática em setembro de 2019, atravessou o oceano Atlântico a bordo de um veleiro que não emite carbono, para não viajar de avião, como parte de seu compromisso pessoal pelo clima.

Enfim, Greta provocou um choque geracional, se tornou uma incontestável e legítima liderança da juventude global; e sobretudo, acrescentou um novo papel social a ser desempenhado nesta época de mudança de conjuntura global diante do colapso ambiental climático: o ativismo ecológico com o tempero subversivo da desobediência civil como o destaque inovador para o perfil clássico e conservador do sujeito ecológico.

É precisamente esse ativismo ecológico e seu engajamento mais profundo que renova o compromisso realmente efetivo com a causa ambiental, subindo um patamar importante no grau de exigência para que especialmente os donos do poder, não sigam com suas práticas antiecologistas. O militante é aquele que combate, que defende, com audácia, veemência e intransigência, a sua causa. Não faz vista grossa, não ignora e sabe que precisa reivindicar por seus direitos, e isso é responsabilizar decisores políticos. Com essa fórmula, rompe-se a ideia da responsabilização restrita ao indivíduo comum como estando centralmente na raiz da crise 
Ensino, Saúde e Ambiente - Número Especial, pp. 44-88, Junho. 2020

ambiental. Rompe-se a narrativa preponderante de que o indivíduo em seu cotidiano é o maior ou o único responsável pela transição à sustentabilidade.

E na gramática do sujeito ecológico brasileiro nestes primeiros seis meses do regime Bolsonaro, o drama social da conjuntura ecopolítica nacional com o retrocesso ambiental se adensa com o drama social da conjuntura ecopolítica global. No Brasil, os tempos do colapso climático global se combinam com os tempos do antiecologismo negacionista tupiniquim como projeto político nacional da extrema-direita no poder, e isso resultou na tragédia amazônica em chamas. Essa nova configuração explosiva do drama social exponencializa decisivamente a militância política nacional, quando este sujeito ecológico sai da zona de conforto da ação individual na esfera doméstica reciclando minimamente seu lixo, e se transmuta em sujeito ecopolítico, um militante ativista ambiental que agrega à narrativa do protesto contra o retrocesso ambiental federal, a narrativa do protesto contra o negacionismo climático do governo brasileiro.

\section{Do sujeito ecológico ao sujeito ecopolítico}

Em 1994, um expoente educador ambiental brasileiro, Marcos Reigota, escreveu um livro emblemático que respondia à pergunta "o que é Educação Ambiental". Inevitável, portanto, não relembrar aqui o que já definia, há vinte e cinco anos atrás, a essência da Educação Ambiental: ela já era explicitamente reconhecida como Educação Política. O que se esperava da Educação Ambiental era a formação de sujeitos políticos, tanto quanto a disseminação de valores para uma consciência ecológica que fosse capaz de criar comportamentos individuais ecologicamente corretos, como a redução do consumo de água, a destinação correta do lixo e a adoção de um consumo sustentável. Se esperava formar cidadãos com capacidade de leitura crítica, de indignação e de mobilização contra a realidade socioambiental injusta e predatória. Essa concepção superava o reducionismo da visão conservadora da Educação Ambiental. Para além do cuidado individual com o lixo, a água, o solo, ou os seres do mundo natural, a Educação Ambiental busca não só mudanças comportamentais que anunciam a sustentabilidade; mas, sobretudo, mudanças políticas, que denunciam e combatem a insustentabilidade. Visa a formação de sujeitos críticos, participativos e comprometidos com uma sustentabilidade socioambiental enquanto opção ético-política. O caminho da sustentabilidade não é apenas uma questão ética e moral, é também questão política e econômica e assim, não basta formar sujeitos ecologicamente conscientes se eles também não forem politicamente atuantes. 
Ensino, Saúde e Ambiente - Número Especial, pp. 44-88, Junho. 2020

Carvalho (2004), por sua vez, se indaga dez anos mais tarde, mas "afinal, quem é esse sujeito ecológico enquanto entidade ideal? Quais são os efeitos que uma identidade ecológica produz na vida cotidiana dos que se identificam com esse universo de valores?" (p. 66). Na sequência, a autora pontua que há uma apreensão ingênua da ideia contida na Educação Ambiental, onde se dissemina frequentemente a ideia simplista de que as pessoas serão ensinadas a serem mais gentis e cuidadosas com a natureza, como uma premissa suficiente para fundamentar a orientação educativa. Carvalho frisa então que é necessário superar essa visão ingênua de Educação Ambiental, porque ela não se reduziria a uma intervenção pedagógica centrada no indivíduo, entendido como uma unidade atomizada e isolada das condições sociais e da relação com o mundo.

Ademais, acrescenta a autora, é frequente constatar que as atividades de Educação Ambiental enfatizam a transmissão de conhecimentos e procedimentos ambientalmente corretos, ensinando como 'fazer o certo' seguindo o princípio do cuidado com a natureza e a preocupação com a sustentabilidade; mas que no limite, tal aprendizagem se resume a obediência às regras que se espera de um cidadão civilizado e literalmente comportado. Diz a autora que "cabe reconhecer que gerar comportamentos individuais ordeiros, preocupados com a limpeza de uma área ou com a economia de recursos ambientais como a água ou a energia elétrica, pode ser socialmente desejável e útil, mas não significa necessariamente que tais comportamentos sejam integrados na formação de uma atitude ecológica e cidadã (...) $O$ grande desafio da Educação Ambiental é, pois, ir além da aprendizagem comportamental" (p. 181), porque "a visão comportamental tende a operar promovendo o reforço de comportamentos ambientalmente corretos e evitando ou punindo os inadequados; 'adestrando' mais do que educando" (p. 184), o que carrega implicitamente uma aprendizagem sutil da disciplina e da norma, a obediência civilizada ao comportamento ecológico esperado dentro de uma sociedade de controle e da ordem capitalista. O currículo oculto aqui é a aprendizagem da subserviência.

É neste contexto que Carvalho (2004) corrobora que o processo educativo deve ser compreendido como um ato político, "cuja vocação é a formação de sujeitos políticos, capazes de agir criticamente na sociedade" (p. 186), lembrando que para a filósofa Hannah Arendt, "a capacidade de ação política é a expressão mais acabada da condição humana" (p. 187). E aqui a autora faz a importante distinção entre comportamento e ação:

Diferentemente dos comportamentos, que repetem padrões aprendidos, a ação passase no plano da atribuição de sentidos às experiências humanas, no qual se criam as regras do jogo social e da convivência. Arendt critica a sociedade moderna porque constata nela a progressiva perda da capacidade de agir em face da sociedade de massas, cuja tendência conformista e homogeneizadora acaba por restringir as possibilidades de ação. Em vez de dar a seus membros a possibilidade de agir e 
Ensino, Saúde e Ambiente - Número Especial, pp. 44-88, Junho. 2020

\begin{abstract}
interferir, a sociedade de massas trata-os como indivíduos isolados dos quais se espera certos tipos de comportamentos, impondo padrões preestabelecidos e esforçando-se por 'normalizar', no sentido de padronizar a conduta dos grupos sociais. (...) A ideia de que os sujeitos se comportam em vez de agirem tomou conta do imaginário moderno. O comportamento substituiu a ação como principal forma de atividade humana. (...) Outro aspecto importante da diferença entre agir e comportar-se é que a ação se dá sempre como expressão de um sujeito no mundo, ou seja, um sujeito que se constitui socialmente e não se reduz a uma interioridade privada, uma existência individual isolada da vida em comum. A ideia de comportamento vem carregada da visão que supõe um sujeito atomizado, apartado e, nesse sentido, 'privado' da esfera das relações históricas e sociais coletivas. Um sujeito sem história e sem vínculos, que apenas se modela aos padrões preestabelecidos e age de forma que consiga a melhor adaptação possível. Uma felicidade adaptativa é a meta da satisfação que esse sujeito do comportamento busca alcançar, em uma sociedade tirânica que o ameaça com a exclusão e o não reconhecimento, se ele fugir às normas (p. 188-189).
\end{abstract}

O que fica evidente com as observações de Carvalho (2004), que cunhou o conceito de ‘sujeito ecológico’ em um momento histórico que era inimaginável que quinze anos mais tarde a comunidade ambiental brasileira tivesse que enfrentar o sistemático desmonte ambiental por dentro do próprio governo federal, é que o perfil do sujeito ecológico idealizado abarcaria em seu repertório identitário, também a ação política, buscando a superação da visão hegemônica que eternamente responsabiliza o indivíduo atomizado pelas respostas à crise ambiental. E agora, diante desse cenário dominado pelo retrocesso ambiental como programa de governo, acrescido pelo colapso climático, torna-se imperativo à Educação Ambiental concentrar esforços na formação do sujeito ecopolítico.

Não estamos mais no período da expansão ou consolidação do ambientalismo pelo tecido social brasileiro, essas foram fases do processo evolutivo do movimento ambiental que definitivamente ficaram no passado. Entramos em uma nova era, em um novo ciclo reiniciando todo processo de defesa ambiental que vigorou a partir dos anos 60. Estamos na fase da retração do ambientalismo, do signo do antiecologismo.

É preciso ter clareza que os tempos são outros, e por esse motivo, as respostas precisam ser as adequadas à essa nova realidade. Diante do retrocesso e do desmonte ambiental, não há espaço para saudar as iniciativas demonstrativas exitosas que merecem ser visibilizadas, as ações positivas prenhes de exemplos de sustentabilidade, na expectativa de fazer acreditar possível construir o caminho da sustentabilidade sem ao mesmo tempo denunciar vigorosamente a insustentabilidade, para desligar automaticamente os motores da degradação ambiental. Os tempos atuais, regidos pelo signo do antiecologismo, exigem uma reação proporcional à mudança de conjuntura: exigem luta, protesto, manifestação; exigem ação política e coletiva. Mas exigem também a capacidade de indignação, exigem a desobediência civil; exigem, no limite, a superação da pedagogia do conformismo e da obediência que acabou por predominar no campo da Educação Ambiental. Exige superar a 
Ensino, Saúde e Ambiente - Número Especial, pp. 44-88, Junho. 2020

conformidade do modelo conservador de Educação Ambiental aos interesses do capital. Não é possível seguir indiferente e alienado diante do abrupto e profundo retrocesso ambiental, anunciando ingenuamente a prática individual dos bons exemplos de sustentabilidade. Exige um tipo de militância ecologista que se faz nas ruas, não em casa nos comportamentos individuais ou nos hábitos de consumo no mercado.

Não basta apenas fazer o que é certo individualmente para se alcançar os resultados almejados, porque o problema é estrutural, não pessoal. O problema é de outra natureza, outra dimensão, que apenas o somatório das ações individuais não dá conta de resolver. As reais e profundas causas da crise ambiental ou simplesmente dos impactos ambientais particulares ficam ocultadas.

A autora afirma ainda, que atualmente parece predominar menos ousadia e mais resignação do que no tempo das origens do ecologismo nos anos 60 , sinalizando para uma grande mudança que subtraiu o espírito subversivo do ecologismo contemporâneo. O movimento ecológico estaria domesticado, estagnado em uma subjetividade conformista, com o espírito da contestação e do protesto controlado.

O vocábulo 'sustentabilidade' se afirmou como uma palavra-chave decisiva no pósRio-92; contudo, toda palavra possui uma carga ideológica capaz de formatar a compreensão do contexto segundo um enquadramento específico. Subliminarmente, o vocábulo 'sustentabilidade' carrega consigo a mensagem ideológica da agenda positiva, demarcada pela construção da sustentabilidade apartada da desconstrução da insustentabilidade. 'Sustentabilidade' ficou dissociada da 'luta ambiental'. Sustentabilidade rima com bons comportamentos ecológicos individuais, mas não rima com contestação e embate contra políticas públicas ecocidas. O farol da sustentabilidade apontou para uma única direção, iluminando apenas um caminho a seguir, enquanto orientação para o sujeito ecológico não se perder em sua travessia individual e solitária rumo à sustentabilidade.

\section{A subversão civilizatória do ecologismo}

O ecologismo é um qualificado como novo movimento social que carrega a marca da subversão da ordem no seu DNA. A ideia da proteção da natureza contra a degradação das condições da Vida no planeta desponta como uma reação no momento histórico que principiavam os diagnósticos científicos de uma crise ambiental que se avizinhava num horizonte próximo se o rumo civilizatório não fosse alterado. O ecologismo surgiu como uma reação contrária à expansão ilimitada e descontrolada do voraz desenvolvimentismo 
Ensino, Saúde e Ambiente - Número Especial, pp. 44-88, Junho. 2020

economicista orientado pelo livre mercado, que se mostrava incapaz de saciar a demanda do metabolismo urbano-industrial de uma sociedade de consumo e ao mesmo tempo manter as bases de sustentação da Vida preservadas, por conta do imperativo do crescimento econômico capitalista que forçou o ritmo da natureza a acompanhar o ritmo industrial para além da capacidade suporte planetária.

Carvalho (2004) afirma que:

Discutir o ecologismo sem situá-lo em relação ao ambiente utópico que lhe dá origem e à sua filiação contracultural seria reduzir a compreensão daquilo que fundamentalmente o inspira e lhe confere poder de atração e convocação à ação. Nele, a visão da natureza como contraponto da vida urbana, tecnocrática e industrial aparece combinada com o sentimento da contestação. O repúdio a uma racionalidade instrumental, aos ideais de progresso, ao individualismo e à lógica do custo-benefício meramente econômico pode ser observado no ideal de uma sociedade ecológica que se afirma como via alternativa à sociedade capitalista de consumo. Ao levar a problemática ambiental para a esfera pública, o ecologismo confere ao ideário ambiental uma dimensão política. A crítica ecológica situa-se entre as vozes contestatórias do estilo de vida contemporâneo, denunciando sua face materialista, agressora do meio ambiente e bélica (p. 48, grifos nossos).

Nesse cenário alarmista, de imediato e como uma forma de ampliar a sensibilização pública à causa ambiental, despontou a narrativa ecologista dos 'profetas do apocalipse' (McCORMICK, 1992) que denunciavam a chegada do colapso ambiental se a civilização moderna não mudasse radicalmente sua trajetória suicida. $\mathrm{O}$ signo ameaçador da denúncia, do combate, da cruzada ambiental, passou a acompanhar o inquieto e indignado ethos ecologista.

Diante da necessidade imperativa de frear o binômio produção econômica-predação da natureza, estabelecendo limites à economia do livre mercado que implicassem em esgotamento dos recursos naturais, erosão genética, perda de ecossistemas, extinção de espécies, desmatamento, acidentes ambientais, poluição, lixo doméstico, industrial, hospitalar; resíduos sólidos, líquidos e gasosos; rejeitos tóxicos, químicos e radioativos; é que o movimento ecológico se estabelece. Ele se funda como um anteparo para estancar o processo de degradação ambiental, o que o faz naturalmente carregar a chaga da subversão por ousar contestar a ordem instituída. E assim, em plena era desenvolvimentista nos anos 60, surge o ecologismo, um estraga-prazeres que invadiu a festa da prosperidade econômica, dizendo que a balbúrdia da economia desgovernada acabou.

A obra do Clube de Roma intitulada "Limites do Crescimento" (MEADOWS et al, 1978) e publicada em 1972, alimentada pela narrativa apocalíptica do colapso ambiental, foi decisiva e emblemática, porque explicita literalmente a ideia da imposição de limites à economia para que os limiares planetários de sustentação da Vida na Terra não sejam ultrapassados. A ideia de se limitar o livre desenvolvimento da economia, absolutamente contra-hegemônica, se forja com o caráter subversivo, contestador da ordem socioeconômica 
Ensino, Saúde e Ambiente - Número Especial, pp. 44-88, Junho. 2020

estabelecida. A rigor, o American Way of Life, paradigma que fundou a sociedade de consumo e de desperdício, estava ameaçado pela contestação ecologista, com o respectivo repúdio a todo o programa da doutrina neoliberal, que prega a não intervenção estatal na economia, para que as leis de mercado possam se expressar livremente, sem controle nem regulamentação.

E a partir de então, na contracorrente do desenvolvimentismo economicista, o ecologismo se institucionaliza progressivamente nos governos por meio de autoridades e colegiados ambientais públicos que definiram políticas, programas, legislações e regulamentações ambientais e tratados internacionais com o exato propósito de demarcar os limites que a economia não poderia ultrapassar para não comprometer a capacidade suporte planetária que poderia colocar em risco a sustentabilidade da Vida e terminar por provocar um colapso ambiental.

É também sintomático o título da obra de Aguilera (1980), "Ecologia, ciência subversiva", publicada em 1980, testemunho evidente de como na época se percebia a ousadia do ecologismo nos seus primeiros passos, dizendo "não" à economia desgovernada, à revelia do contexto das leis ecológicas que apresentam limites a serem obedecidos. Desponta desse contexto, a tensão que passou a antagonizar o desenvolvimento com a sustentabilidade, uma delicada tensão político-ideológica que só veio a ser minimamente superada por ocasião da Conferência do Rio, quando se institui o paradigma do Desenvolvimento Sustentável, ou seja, o desenvolvimentismo finalmente orientado pelo ecologismo. No limite, acabou prevalecendo o bom senso com algum equilíbrio regulatório sobre o poder absoluto do capital.

Para caracterizar o ecologismo com essa marca da subversão, importa lembrar também que, ainda nos tempos da maturação do pensamento ecologista, no século IX, a ideia da subversão ecologista já se fazia presente na obra de Henry David Thoreau, um dos pensadores clássicos da literatura ecologista; autor de "Desobediência Civil" (THOREAU, 2016) e de "Walden, ou Uma Vida nos Bosques" (THOREAU, 2014). Em Desobediência Civil, publicado em 1849, Thoreau elaborou um manifesto revolucionário à sua época, desafiando obrigações e deveres de governos considerados injustos.

Algo muito similar ao conceito da Objeção de Consciência, que é a invocação do direito de se abster de realizar um dever comum a toda sociedade, posto que essa obrigação seria contrária às convicções religiosas, éticas ou políticas do sujeito reivindicante desse direito; mas desde que ele se responsabilize como contrapartida, por cumprir atividade alternativa. Silva e Santos (2012), que efetuam uma análise da objeção de consciência no contexto do uso de animais em laboratórios dos cursos de ciências naturais nos estabelecimentos universitários, frisam inclusive que essa recusa ética é uma garantia 
Ensino, Saúde e Ambiente - Número Especial, pp. 44-88, Junho. 2020

constitucional no país. A prática da vivissecção de animais, mesmo que para fins didáticos ou científicos, se resume em crueldade animal penalizada pela Lei de Crimes Ambientais.

Em Walden, publicado em 1854 como um protesto contra a civilização industrial e sua face capitalista, Thoreau (2014) elabora um ensaio autobiográfico de sua experiência de absoluta imersão na natureza, em busca de um estilo de vida simples e frugal, para descobrir quais seriam as verdadeiras necessidades essenciais do ser humano, longe da influência da vida domesticada no espaço urbano-industrial.

Em suma, o ecologismo na sua origem é subversão. Porém, com a instauração do pacto do desenvolvimento sustentável, a subversão foi apaziguada em nome da confiança depositada no pacto estabelecido por ocasião da Rio-92. Porém, com a quebra do pacto da sustentabilidade na medida que a ascensão ao poder do signo do antiecologismo impôs o retrocesso ambiental como política de governo, a nova conjuntura ecopolítica recolocou o ecologismo diante da agenda da refundação do ânimo subversivo, rompendo os grilhões da ordem domesticada do sujeito ecológico conformado a um enquadramento específico de como comportar-se individualmente na transição ecológica.

\section{A hegemonização do modelo conservador de Educação Ambiental no Brasil}

Em outra ocasião (LAYRARGUES, 2018 b) argumentamos que a Educação Ambiental brasileira possui fortes indícios de estar hegemonicamente alinhada ao espírito capitalista, reproduzindo acriticamente suas lógicas e valores, e renunciando ao seu papel problematizador na crítica anticapitalista e na transformação social do status quo. A Educação Ambiental brasileira foi instrumentalizada e tornou-se um aparelho ideológico de Estado hegemonicamente dominado pelo interesse econômico da burguesia a serviço de um modelo conservador e reprodutivista de Educação, obediente à reprodução social da formação capitalista e subserviente à sociabilidade do livre mercado. A Educação Ambiental brasileira teria se enquadrado fielmente na perspectiva que se espera de uma educação voltada à questão ambiental dentro de uma sociedade capitalista: reformista na forma, pragmática no conteúdo. Assim ajustada, a Educação Ambiental passou a contribuir funcionalmente com a reprodução do ethos capitalista, servindo como a mesma referência uniforme e indistinta para a mesma sociedade de classes.

Camuflada pelo legítimo processo pedagógico de formação e de conscientização ambiental, a cultura capitalista sutil e subliminarmente passou a ser disseminada na intencionalidade político-pedagógica da Educação Ambiental, por meio da sua recorrente 
Ensino, Saúde e Ambiente - Número Especial, pp. 44-88, Junho. 2020

associação com a mensagem ecológica, insistindo-se na mensagem de que a solução para a sustentabilidade passa pelo mercado. O capitalismo expressou claramente seu poder de controle, por meio do exercício da força simbólica de dominação, transmitindo incessantemente seu estilo de pensamento para dentro do campo da Educação Ambiental. Agora, salvo em poucos espaços entrincheirados da perspectiva Crítica da Educação Ambiental numa fração do setor acadêmico e dos movimentos sociais, a Educação Ambiental brasileira é exatamente a mesma Educação Ambiental que se esperaria encontrar em uma sociedade capitalista. Se investiu da ideia do fim das ideologias e naturalizou o capitalismo, aceitando-o passivamente como a doutrina societária definitiva e inquestionável, que basta reformar para corrigir suas distorções; sem jamais combater sua intrínseca lógica predatória, contribuindo assim com sua reprodução sob as melhores condições de temperatura e pressão: sem contestação ou oposição alguma.

Naturalizando o capitalismo e ignorando a luta de classes do seu enquadramento no ato pedagógico, esse modelo conservador e reprodutivista se forja a partir da ideia de que a missão civilizatória da Educação Ambiental seja a de avançar sobre o terreno da ignorância, mas não o da ganância. Assim posto, o problema a lidar está no fomento à disseminação do conhecimento científico-ambiental para superar o comportamento individual ecologicamente inadequado, marginalizando a dimensão estrutural dos conflitos sociais na esfera política e econômica em torno de interesses de classe contraditórios e relações de poder de acesso e uso dos bens ambientais entre capital e trabalho totalmente desigual. Assumindo esse postulado, adota uma perspectiva difusionista e normativa, torna-se uma educação de deveres, e não de direitos, e assim o êxito da tarefa educadora dependerá unicamente da divulgação apropriada da mensagem ecológica a todos indistintamente, o que é na verdade uma impossibilidade para uma sociedade de classe.

Esse modelo conservador e reprodutivista da Educação Ambiental cumpre seu papel funcional quando conquista hegemonia a partir do controle de toda a poderosa estrutura de difusão ideológica investida pelo robusto sistema público institucional e legal que é o campo político da Educação Ambiental brasileira, que conta com uma Política e um Programa Nacional de Educação Ambiental e diversos instrumentos de gestão pública, organizado de modo a garantir a veiculação da mensagem sobre a formação e conscientização ambiental influenciando a mais ampla audiência na escola e na sociedade acerca do papel social a ser desempenhado pelo sujeito ecológico diante dos constrangimentos ambientais. Esse modelo passa a controlar seletivamente a mensagem que deve fluir pelo sistema político da Educação Ambiental, bem como pela Comunicação Ambiental midiática em geral, para todos os espaços escolares e não escolarizados, difundindo orientações precisas sobre o pensar e fazer 
Ensino, Saúde e Ambiente - Número Especial, pp. 44-88, Junho. 2020

as práticas pedagógicas vinculadas à questão ambiental, sempre alinhadas à perspectiva do ambientalismo de mercado. E ao mesmo tempo, com a imposição da ordem e disciplina da norma, impede a veiculação de mensagens de natureza subversiva e contestatória que eventualmente ofereçam resistência ou ameaça à ordem social capitalista. Em nome da salvação da natureza, difunde-se a propaganda doutrinadora do capital e do apaziguamento social, posto que aqui nesta fictícia sociedade sem classes, todos estariam de mãos dadas juntos pela cruzada ambiental. Assim feita essa associação subliminar, o caminho da salvação da natureza necessariamente passa pelo mercado.

Exercendo seu poder de controle seletivo sobre a mensagem, esse modelo conservador e reprodutivista conquista hegemonia quando dissemina consensos absolutos e inquestionáveis que giram em torno da difusão exclusiva da agenda positiva, em torno da pauta dos louváveis 'bons exemplos', das 'boas práticas' exitosas de sustentabilidade, que merecem o título de inspiradoras para pavimentar o caminho certo a seguir pelo cidadão ambientalmente responsável; enquanto necessariamente omite a pauta negativa, ocultando os elementos estruturais da insustentabilidade inerente à lógica do capitalismo. Esse ocultamento torna invisível o racismo, o conflito e a desigualdade socioambiental, fenômenos que evidenciaram a dimensão conflituosa intrínseca da sociedade capitalista. Torna invisível as lutas populares de resistência dos movimentos sociais, contribuindo assim com o fíctício apaziguamento social, e é negada a compreensão da lógica da degradação ambiental ser atravessada pela luta de classes e determinada pelo capitalismo.

Nesse duplo papel da difusão ideológica, o estabelecimento da honrosa norma-padrão e a interdição da problematização do contraditório; o ocultamento das contradições é fundamental para assegurar a estabilidade da ordem social sem necessidade de se recorrer aos aparelhos repressores de Estado para reprimir a sua contestação, pois desempenha função preponderante na conformação e acomodação dos sujeitos, apaziguando o poder subversivo e eliminando a paisagem da arena pública como espaço de manifestação cidadã comprometida com a defesa ambiental.

Via de regra, a transmissão desses consensos inquestionáveis abrange variados aspectos da sociabilidade do mercado, que reverberam maciçamente sobre os atos pedagógicos, como por exemplo, em torno do mantra da reciclagem como ideia-chave exclusiva para a Educação Ambiental no contexto dos resíduos sólidos. Mantra reproduzido fiel e cotidianamente pelo Estado e pela escola, sem contextualização sobre o ciclo de vida da mercadoria, nem problematização acerca do limitado alcance da reciclagem no combate ao desperdício dos recursos naturais. Mantra que permanece intrinsecamente vinculado à ciranda 
Ensino, Saúde e Ambiente - Número Especial, pp. 44-88, Junho. 2020

do comprar e vender do mercado, posto que agora se adere à reciclagem e ao mercado da logística reversa. Sim, para o capitalismo, a salvação da natureza decididamente passa pelo mercado. Por outro lado, esse modelo conservador e reprodutivista não estabelece um consenso igualmente absoluto e inquestionável para eliminar a lógica estruturante do desperdício dos recursos naturais, por meio da negação da raiz do problema, a obsolescência planejada e a propaganda do consumismo, abrigados sob o manto cultural do amplamente disseminado 'American Way of Life'. A obsolescência planejada e a propaganda do consumismo são os motores determinantes da lógica do desperdício, que na sociedade capitalista, não podem ser desligados, porque são determinados pela produtividade e competividade em uma economia de livre mercado.

Daí o caráter meramente reformista, deste modelo conservador de educação, pois aponta para soluções que ambientalmente apenas atenuam os efeitos, enquanto silencia as causas estruturais do desperdício dos recursos naturais no metabolismo industrial capitalista, mantendo intactos os fundamentos do modo de produção orientado pelo lucro. Na balança entre os benefícios ambientais e os econômicos, a reciclagem certamente assegura a criação de um novo e robusto mercado dentro da indústria da despoluição, o da logística reversa, mercado dependente da manutenção da lógica do desperdício vigorando no estilo de vida capitalista: a reciclagem é parte constituinte intrínseca da lógica de mercado, e a Educação Ambiental se tornou parte indissociável dessa engrenagem. Em outras palavras: para ativar o mercado da logística reversa, é fundamental que haja consumo excessivo e de mercadorias 'feitas para quebrar'; e a Educação Ambiental funcionalmente contribui com a formação da mentalidade passiva e subserviente a essa lógica (LAYRARGUES, 2018 c).

O mesmo atualmente vêm ocorrendo recentemente com relação à guerra mundial declarada contra os canudinhos plásticos ${ }^{20}$; inacreditavelmente apontado como 'um dos principais vilões do meio ambiente' a ser combatido em nome da limpeza dos oceanos. Como se fosse possível a eliminação da produção do canudo plástico por meio do boicote individual no ato do consumo, ao se praticar o princípio do Recusar. E como se a eliminação do canudo plástico realmente fosse um pontapé inicial para a internalização de atitudes mais coerentes com a responsabilidade ambiental, premissa sustentada pela lógica liberal do somatório das ações individuais contribuírem decisivamente para o bem comum, apostando-se que é apenas uma questão de tempo para que todos acabem adotando o mesmo comportamento individual. Mas é uma fórmula que ignora a política, que ignora especialmente a conjuntura que poderia

\footnotetext{
${ }^{20}$ https://g1.globo.com/bemestar/noticia/mundo-declara-guerra-ao-canudo-de-plastico-um-dos-principaisviloes-do-meio-ambiente.ghtml
} 
Ensino, Saúde e Ambiente - Número Especial, pp. 44-88, Junho. 2020

demonstrar ser esse um problema menor, mas colocado convenientemente no centro das atenções para se desviar o olhar daquilo que realmente importa.

Mas essa postura apenas naturaliza a essência do canudinho de plástico, que é sua descartabilidade. E assim, combate-se uma mercadoria descartável, mas não se combate a descartabilidade das mercadorias.

A angústia humana com o trágico diagnóstico da crise ambiental segue capturada e canalizada para o enfrentamento de uma batalha inócua que em nada resultará na mudança do sistema econômico ecocida. E não se preocupem aqueles tarados preocupados com a extinção dos canudinhos plásticos, que não conseguem ver um refrigerante sem abrir mão do prazer da sucção para saborear o conteúdo da sua latinha: o mercado eco friendly, claro, oferece alternativas 'ecológicas' ao canudo plástico, com incríveis modelos de metal, vidro e até comestíveis, portadores do nobre signo da biodegradabilidade. Um produto moderno, diferenciado, que ao ser triunfalmente inserido na latinha, demonstrará a todos ao seu redor que aquele proprietário dessa mercadoria ecológica é um sujeito em dia com seu compromisso servil com a causa ambiental, dando a sua cota de contribuição individual para evitar a poluição dos oceanos. Menos uma mercadoria descartável sendo consumida, enquanto que o paradigma da descartabilidade segue inabalado, com seu acelerado ritmo de desperdício dos recursos naturais, lá na produção, como uma decisão empresarial estratégica; e bem longe do alcance do consumo.

Não é só a maneira como o cidadão se veste, come, mora, se locomove, compra. Aquilo que se entende por 'estilo de vida' deveria comportar também a maneira como o cidadão interage com as lideranças políticas. Ou não interage.

Não basta apenas o voto em um candidato com perfil ecológico depositado numa urna a cada quatro anos. Essa fraca interação com o governo pode se tornar mais ativa, mais constante, mais consistente. Afirma-se que sete bilhões e meio de pessoas tomam decisões diariamente, ou seja, potencialmente esses sete bilhões e meio de pessoas poderiam causar uma revolução se agissem em sintonia com o mesmo propósito orientado pela transição ecológica. Nessa perspectiva, a questão é apenas de dar escala ao processo de conscientização ambiental. Mas diante dos inexpressivos números que mostram a quase inexistente presença de consumidores verdes ou conscientes, não parece muito sensato apostar na conversão comportamental do indivíduo como uma via única que confia no poder de transformação do comportamento do consumo e despreza o poder de transformação da ação política.

Não parece muito promissor o futuro de uma sociedade preenchida majoritariamente por consumidores verdes. Até que ponto esse engajamento individual nos hábitos de consumo 
Ensino, Saúde e Ambiente - Número Especial, pp. 44-88, Junho. 2020

conseguem interferir na obsolescência planejada? E na descartabilidade das mercadorias em geral e das embalagens especificamente? Esse consumidor verde vai deixar de trocar seu celular anualmente? Vai abrir mão do consumo repetitivo de novas mercadorias porque a antiga quebrou ou se tornou tecnologicamente obsoleta? Vai eliminar por completo os legumes e verduras de sua mesa produzidos com agrotóxicos? E mesmo que toda a população brasileira deixe de consumir legumes e verduras sem agrotóxicos, a Empresa Brasileira de Pesquisa Agropecuária (EMBRAPA) vai mudar sua orientação política e a sojicultura no Cerrado vai deixar de despejar agrotóxicos? Vai zerar suas emissões de carbono? Vai destinar à reciclagem seu óleo usado de fritura? E que tipo de ação individual no âmbito privado o cidadão hoje e agora pode fazer para estancar o acelerado ritmo de desmatamento e conversão do solo no Cerrado? Qual papel o consumidor verde pode cumprir para frear a degradação ambiental na região do MATOPIBA ${ }^{21}$, quando o próprio governo federal decidiu que esse território representa a última fronteira do agronegócio no Cerrado? Deixar os canudinhos de plástico de lado vai cessar a produção de descartáveis? Deixar de consumir produtos feitos à base do óleo de palma da Malásia vai assegurar que essa indústria extrativa feche suas atividades, salvando o orangotango da iminente extinção que se encontra em função da expansão do plantio da palma? Abrir mão do luxo do ouro na indústria das joias cessará o garimpo ilegal de ouro na Amazônia? Como o consumidor verde vai provocar na megamineração a responsabilidade ambiental? Para salvar as abelhas da extinção por causa da ação devastadora dos agrotóxicos, não seria mais sensato que o governo interditasse a produção e uso dos agrotóxicos comprovadamente nocivos às abelhas?

E como ficam os interesses dos setores econômicos do setor primário da economia, esse que concentra riqueza a partir da extração dos recursos naturais, esses entendidos como banalmente como commodities que são comercializadas em um mercado global regido pelo menor preço? Como vão assegurar competitividade num cenário que têm a proteção ambiental como um entrave aos negócios porque o aparato de defesa ambiental encarece a produção? Como esse consumidor ecologicamente consciente vai individualmente frear o ímpeto da expansão da propriedade privada latifundiária adentro de territórios indígenas, quilombolas ou de áreas protegidas? Como o seu empenho em economizar água evitando o desperdício doméstico vai impedir os conflitos socioambientais em torno do acesso privado da água como uma mercadoria? E isso em um país que é campeão nas estatísticas de assassinatos de lideranças ambientais, não parece mesmo nada sensato.

\footnotetext{
${ }^{21}$ MATOPIBA é o acrônimo formado com as iniciais dos Estados do Maranhão, Tocantins, Piauí e Bahia, para designar a extensão territorial que abrange parcialmente essas quatro Unidades Federativas.
} 
Ensino, Saúde e Ambiente - Número Especial, pp. 44-88, Junho. 2020

Como o consumidor verde reverterá o tsunami antiecologista que varreu o país no regime Bolsonaro? Que tipo de comportamento individual no âmbito doméstico é capaz de reverter o retrocesso ambiental? Que ato de consumo consciente no mercado é capaz de alinhar o governo brasileiro novamente ao firme combate das mudanças climáticas?

E no limite, cabe lembrar que soluções da ordem do mercado estão presas dentro do paradigma da ditadura da economia comandando tiranicamente o destino da humanidade. As narrativas justificadoras que reconhecem haver um monumental prejuízo econômico ao Brasil em função do retrocesso ambiental, são narrativas dentro da ordem onde a própria economia se encarrega de promover a auto regulação do mercado.

Para fazer parte da solução da crise ambiental, não basta ser um consumidor ecologicamente consciente; é também necessário ser um cidadão politicamente atuante. Não basta ser ecologicamente alfabetizado, é preciso também ser sociologicamente formado. Não basta adotar atitudes altruístas exemplares dando o bom exemplo do 'bom civilizado', que não passa de uma idealização semelhante a do bom selvagem rousseauniano. É preciso também revolta, indignação, sangue nos olhos e punhos cerrados, encarando furiosamente aquele que compromete as condições ambientais e ameaça o sistema da Vida.

Esse modelo conservador e reprodutivista da Educação Ambiental investe muita energia no combate ao desperdício dos recursos naturais, silenciando a existência de conflitos socioambientais que atravessam essa pauta. Esse modelo combina fielmente com a perspectiva do "Evangelho da Ecoeficiência" de Alier (2007), que representa a visão de mundo dogmática do setor econômico sobre a questão ambiental: um mero problema técnico de gestão de recursos naturais, que passa longe do problema da negociação política dos conflitos socioambientais. Nesta formulação clássica, os recursos naturais são apresentados ideologicamente como bens raros e escassos, mas jamais como bens submetidos a distintos regimes de propriedade, em disputa por interesses antagônicos de apropriação e de uso. Nesse cenário, abençoado pelo deus mercado, ganha o reino do céu aquele que professa a sua fé na cruzada individual contra a prática do desperdício; e não contra a avidez e ganância dos donos do poder, fator determinante da lógica do desperdício que permanece intacto.

O resultado desse modelo conservador e reprodutivista da Educação Ambiental que conquistou hegemonia é a formação de um sujeito ecológico manipulado, ingenuamente alinhado ao pensamento social capitalista: sujeitado pelo adestramento ambiental para se adaptar voluntariosa e altruisticamente a novos comportamentos individuais.

Assim capturado, absorve obediente e passivamente o repertório de valores, conhecimentos e habilidades que o condicionam a pensar e a agir na direção da 
Ensino, Saúde e Ambiente - Número Especial, pp. 44-88, Junho. 2020

sustentabilidade apontada exclusivamente pela perspectiva do ambientalismo de mercado, reproduzindo acriticamente sentidos ideológicos que em nome da 'conscientização ambiental', se prestam a realizar o interesse do capital.

Assim conformado, esse sujeito ecológico se vê investido sempre pela responsabilização individual de si próprio como um 'bom consumidor', calcado na ação individual na esfera privada, tornando-se plenamente capaz de contribuir com mudanças superficiais e reformistas, e totalmente incapaz e privado do exercício cidadão na luta política coletiva pela transformação socioambiental, pautada pela crítica anticapitalista do fundamento estrutural da insustentabilidade do modelo societário baseado na propriedade privada e no livre mercado. Combinando, como diria Paulo Freire (2000) "eficácia técnica e ineficácia cidadã a serviço da minoria dominante”.

Assim domesticado, esse sujeito ecológico civilizado mas despolitizado, se torna pacificamente instrumental ao sistema, porque só atua a favor de uma sustentabilidade muito particular, fazendo individualmente a 'sua parte' estritamente dentro da regra, ignorando a crítica ecopolítica e a luta coletiva para interromper a lógica predatória intrínseca ao capitalismo: cobrando políticas públicas regulatórias do Estado sobre o Mercado, para orientar de uma vez por todas o desenvolvimento econômico na direção da sustentabilidade, porque o tempo está se esgotando. Temos formado então o sujeito ecológico, mas não o sujeito ecopolítico, que foi privado da formação e exercício do seu direito político.

E dessa forma, instrumentalizada para se tornar subserviente ao capital, a Educação Ambiental brasileira abraçou o conservadorismo pedagógico e teve como resultado final, seu conteúdo crítico ecopolítico esvaziado, seu poder subversivo pacificado, sua possibilidade de formação de ativistas ecológicos suprimida, seu potencial contestatório neutralizado, sua resistência anticapitalista sufocada, sua radicalidade do rumo civilizatório orientado pela transformação social anulada.

Assim constitui-se o papel funcional do modelo conservador e reprodutivista da Educação Ambiental, que parece ter alcançado plena hegemonia no Brasil: um aparelho ideológico de Estado que visa reproduzir a cultura, os valores e o modo de vida próprio de uma sociedade capitalista e sua economia de livre mercado; mantendo sutilmente o controle sobre a ordem social que exige obediência ao sacrifício dos direitos ambientais e humanos para satisfazer o voraz apetite neoliberal por recursos naturais, evitando por conseguinte, a dissidência subversiva do ecologismo popular, ou seja, impedindo a manifestação e o protesto do ativismo ecológico que poderia ameaçar a ordem capitalista que só pode funcionar à base da opressão. 
Ensino, Saúde e Ambiente - Número Especial, pp. 44-88, Junho. 2020

Atendendo aos interesses do capital e contrariando os interesses da classe trabalhadora, essa Educação Ambiental estaria forjando um sujeito ecológico ideologicamente manipulado pelos interesses do mercado, estimulado a se esforçar altruisticamente em atitudes exclusivamente individuais e unicamente dentro da esfera privada.

De modo coerente com o pressuposto funcional básico da sociedade capitalista, onde se espera que cada um faça voluntaria e conscientemente a sua parte, porque assim todos estariam contribuindo com a sociedade como um todo, essa Educação Ambiental estaria privando o educando do estímulo ao exercício da cidadania na esfera pública, na ação política. Se espera que ele, o educando, mude seus hábitos e comportamentos considerados condenáveis do ponto de vista ambiental, mas não se espera que esse mesmo educando passe a agir na condenação de políticas públicas ou planos de negócios empresariais predatórios do ponto de vista ambiental; protagonizados por governos, parlamentares e empresários regidos pelo signo do antiecologismo e empenhados no desmonte ambiental para destravar a economia.

Parece haver uma significativa prevalência na Educação Ambiental brasileira marcada pela potencialização da formação da consciência ecológica de modo totalmente desproporcional em relação à formação da consciência ecopolítica, como objetivos últimos de aprendizagem. Não há neste modelo conservador e reformista ora predominante no país, um estímulo ao engajamento coletivo na luta política na mesma proporção em que se estimula o engajamento individual na redução do desperdício dos recursos naturais.

E é deste horizonte, de uma Educação Ambiental controlada e domesticada, que o tempo histórico do drama social ecopolítico brasileiro demarcado pelo signo antiecologista e negacionista climático justificador do desmonte ambiental, se põe como desafio para a superação dessa condição da subjetividade amordaçada, na medida que o espírito subversivo e o poder da contestação desapareceram do campo da Educação Ambiental no Brasil. A superação da histórica e densa cooptação ideológica é a condição básica para a esperada e necessária formação de sujeitos ecopolíticos.

\section{Epílogo: a formação do sujeito ecopolítico na contestação do antiecologismo}

Se a fraca sustentabilidade no desenvolvimentismo brasileiro e a incapacidade do Estado de resguardar as boas condições ecológicas das florestas e das águas sob jurisdição nacional não é fruto única e exclusivamente da ignorância ecológica da população em geral; mas fundamentalmente, da ganância econômica da elite brasileira com sua insaciável sede de 
poder, que se acostumou a prosperar em um país inventado com nome de árvore a partir do saque sistemático aos recursos naturais, e que vê na defesa ambiental um obstáculo ao livre mercado que precisa ser eliminado simplesmente para se reduzir os custos de produção das commodities nacionais no mercado global; os sentidos dessa frágil sustentabilidade no desenvolvimentismo do país, determinados pela ganância econômica, precisam ser incorporados no vocabulário da Educação Ambiental, mesmo que isso implique em um desconforto de adequação das premissas convencionais já consolidadas no campo.

O desafio do educador ambiental não é somente de enfrentar a ignorância, contribuindo com o desenvolvimento de uma consciência ecológica; é também o de enfrentar a ganância, contribuindo com o desenvolvimento de uma consciência política. Mas fundamentalmente, agora não se trata mais de ensinar o credo da obediência plena à normapadrão exemplar da cartilha da sustentabilidade elaborada pelo mercado, mas de ensinar a atitude da desobediência civil e da rebeldia contestatória contra este sistema opressor, para se aprender a fazer oposição política civilizadamente, segundo as regras democráticas de participação e controle social, infelizmente como uma atitude ainda bastante incomum de se contribuir atualmente com a pavimentação da sustentabilidade.

Aprender a contestar, aprender a reivindicar, aprender a protestar, aprender a agir coletiva e politicamente para defender o ambiente: essas são as novas aprendizagens que emergem da libertação do espírito subversivo e do sentimento de indignação, sufocados em nome da ordem de uma compreensão muito particular e limitada de sustentabilidade, restrita ao universo do mercado, que só se interessa em ensinar a obedecer e cumprir ordens disciplinadamente.

Essa premissa revela novas agendas programáticas ao campo da Educação Ambiental, impondo um repensar sobre o repertório dos objetivos desse campo educativo. A pergunta essencial aqui é: a Educação Ambiental ensina a fazer política como um dos meios de enfrentar a crise ambiental? Qual é o papel civilizatório atual da Educação Ambiental nesta dramática inflexão do retrocesso ambiental regido pelo signo do antiecologismo negacionista?

Nessa conjuntura, cai o predomínio ou quase exclusividade da ampla agenda da alfabetização ecológica na expectativa de formação de cidadãos-consumidores individualmente eco responsáveis, para compartilhar as luzes do palco do ato pedagógico, a agenda da alfabetização ecopolítica, na expectativa de que esses cidadãos-consumidores individualmente eco responsáveis não sejam politicamente ingênuos, e assim possam desenvolver conhecimentos, atitudes e valores coerentes para a atuação coletiva na defesa ambiental na vida política, participando e cobrando a participação e controle social na 
Ensino, Saúde e Ambiente - Número Especial, pp. 44-88, Junho. 2020

construção de políticas públicas orientadoras do desenvolvimentismo pautado pela sustentabilidade.

Os novos tempos regidos pela barbárie do signo do antiecologismo no coração do poder nacional, exigem da Educação Ambiental um redobrado empenho na formação do sujeito ecopolítico, aquele sujeito ecológico que descoloniza seu imaginário cooptado e ultrapassando os limites do reducionismo do individualismo meritocrático, se investe do papel social da militância ecológica, exercitando sua cidadania política enquanto um 'ativista' da causa ambiental, para subversivamente retomar o caminho da civilidade no convívio humano com e no planeta Terra. Desse drama social ecopolítico, afinal, há a promissora esperança da emersão de uma nova pedagogia a preencher de ânimo o campo da Educação Ambiental.

Assim, a resistência contra o desmonte ambiental, que representa o ponto de inflexão dessa oportunidade para a superação do drama social ecopolítico brasileiro na encruzilhada do signo antiecologista; a partir do campo social da Educação Ambiental, inevitavelmente passa por dois caminhos simultâneos: pela recuperação do espírito subversivo e contestatório da origem do ecologismo presente nos anos 60, e pela agenda programática de formação de ativistas ambientais com valores, conhecimentos e habilidades suficientemente capazes de preencher o espaço público com o necessário controle e participação social na arena democrática decisória, mas também na militância reivindicatória de direitos, na ausência deles.

É neste pano de fundo que, quatro dias depois do primeiro turno das eleições presidenciais em 2018, admitindo que a questão ambiental representava um entrave ao desenvolvimento, Bolsonaro afirmou que, além de fundir o Ministério do Meio Ambiente ao Ministério da Agricultura, de explorar economicamente a Amazônia, e de tirar o Brasil do Acordo de Paris sobre as Mudanças Climáticas, pretenderia também acabar com o que chamou de 'ativismo ambiental xiita',22, além de ter levantado suspeitas sobre a idoneidade das ONGs, e por esta razão, ter suspendido os convênios e parcerias do Ministério do Meio Ambiente com essas entidades da sociedade civil organizada ${ }^{23}$.

Rebeldia, protesto, reivindicação, contestação, subversão, são vocábulos pertencentes a um mesmo universo de personalidade reativa que afronta o poder instituído e desobedece indisciplinadamente os limites do proibido imposto pela ordem social disciplinadora; e possuem sentidos que estão muito próximos daquilo que se convencionou pejorativamente

\footnotetext{
${ }^{22}$ https://www1.folha.uol.com.br/poder/2018/10/bolsonaro-diz-que-pretende-acabar-com-ativismoambiental-xiita-se-for-presidente.shtml

${ }^{23}$ https://g1.globo.com/politica/noticia/2019/01/16/ministerio-do-meio-ambiente-suspende-convenios-eparcerias-com-ongs-por-tres-meses.ghtml
} 
Ensino, Saúde e Ambiente - Número Especial, pp. 44-88, Junho. 2020

como 'radical' ou equivocada e preconceituosamente como 'xiita', tido como termo equivalente pejorativo ao extremismo irracional. É contra esse espírito que anima o agir político do humano que Bolsonaro se coloca contra e se empenha em eliminar.

A contestação ecopolítica, o espírito subversivo do ecologismo que inquestionavelmente se levantaria contra o desmonte ambiental público, não seria tolerado em seu governo. Afinal, o protesto da resistência ecologista é outra dimensão do 'entrave ambiental' que necessariamente viria a ser reprimida e domesticada no seu governo, para erigir o seu 'Caminho da Prosperidade', que definitivamente não cruza com o caminho da sustentabilidade. Para Bolsonaro, na mesma medida que os obstáculos ambientais do desenvolvimento a qualquer custo devem ser suprimidos, também esses sujeitos de vontade política, estorvos que devem ser suprimidos para que toda resistência popular contra o projeto de governo da economia de rapina que sequestrou o país seja neutralizada e não incomode a ordem.

Bolsonaro nunca esclareceu quem seriam esses 'perigosos' ativistas ambientais xiitas que deveriam ser eliminados; em nenhum momento explicitou qual seria o perfil de um ativista qualificado pejorativa e equivocadamente como xiita. Mas apesar disso, por meio de outras falas com linguagem ameaçadora, fica claro quem é esse sujeito incômodo que precisa ser eliminado. Quando Bolsonaro dizia que no seu governo o Ministério do Meio Ambiente não iria mais atrapalhar o desenvolvimento do país, ele automaticamente define o perfil dos ativistas ambientais xiitas: aqueles que vinham se colocando como obstáculo contra o interesse econômico dos setores produtivos causadores de degradação ambiental e dos conflitos socioambientais. Na concepção da presidência da república, é exatamente quem 'atrapalha' a vida de quem quer "produzir e empreender no Brasil". E exatamente por isso, o ativismo ambiental passou a ser compreendido pelo governo como uma postura radical e extremada que deve ser censurada e eliminada.

Os xiitas são aqueles que não limitam o exercício de sua cidadania ambiental pelo anúncio das boas práticas de sustentabilidade restritas ao seu universo privado, mas que buscam ações mais consequentes, tomando posições políticas pública e coletivamente, ou seja, lutando contra as práticas produtivas predatórias em todas as áreas onde a prática social se realiza.

Esses xiitas investem sua 'consciência ecológica' não apenas na assimilação de novos comportamentos individuais de uma gestão ambiental doméstica; mas com suas consciências políticas, atuando nos espaços públicos e democráticos, porque guardam a compreensão esclarecida que não tem nenhum sentido cuidar ingenuamente dos efeitos sem ao mesmo 
Ensino, Saúde e Ambiente - Número Especial, pp. 44-88, Junho. 2020

tempo combater as causas estruturais do modelo produtivo baseado na economia de rapina e na exploração dos recursos naturais e humanos adotado no seu território.

Esses ativistas ambientais (des) qualificados como xiitas não apenas sonham, como também constroem o futuro; denunciam e lutam por um outro modelo de desenvolvimento que não seja mais instrumentalizado pela economia de mercado e que recoloque o bem estar humano e a proteção da natureza na centralidade desse desenvolvimento.

Esses ativistas ambientais demonizados como xiitas são sim os militantes ecologistas alinhados ao pensamento ideológico de esquerda, os ecos socialistas, mas não se entrincheiraram ardilosa e sub-repticiamente no campo ambientalista apenas para atacar deslealmente o capitalismo. São os ecologistas que compreendem que a lógica e a dinâmica do capitalismo é intrinsecamente insustentável e produtora de injustiça e desigualdade social e ambiental, e que portanto, compreendem que a degradação ambiental no capitalismo é inevitavelmente atravessada pelos interesses da luta de classes.

Esses ativistas ambientais demonizados como xiitas nem precisam ser identificados como os 'melancias', esses eco socialistas verdes por fora e vermelho por dentro. Qualquer um com uma consciência mínima de que com a Vida não se negocia, se cuida; se soma ao esforço coletivo de defender a Vida quando esta se encontra ameaçada.

Esses ativistas ambientais rotulados como xiitas estariam, segundo a "cruzada bolsonariana", espalhados em muitos espaços em nossa sociedade, tanto nos órgãos ambientais governamentais como nas organizações da sociedade civil, tanto nos movimentos sociais que militam por direitos humanos e ambientais em busca de justiça socioambiental como nas escolas e universidades públicas. Contudo, se os ativistas ambientais xiitas no interior do governo podem ser controlados pelo terror do poder hierárquico institucional do órgão público, com sua força da retaliação como política de silenciamento alinhada ao discurso do 'desaparelhamento ideológico' do Estado na área da gestão ambiental; os ativistas ambientais xiitas na sociedade organizada, além de ser distorcidamente criminalizados, precisam ser demonizados como vilões infernais a serem expurgados pelo poder simbólico da desqualificação de todas as suas virtudes que lhe conferem legitimidade pública pelo agir em nome do interesse comum e do patrimônio coletivo.

Assim, entre tantos outros descalabros, a pretensão de colocar um ponto final no ativismo ambiental xiita, segue seu caminho quando constrange e limita a participação da sociedade civil nos órgãos colegiados que democraticamente dão sustentação às políticas públicas ambientais; como o Conselho Nacional do Meio Ambiente. Redução de um 
Ensino, Saúde e Ambiente - Número Especial, pp. 44-88, Junho. 2020

importante espaço público democrático justificado tão somente em nome do ilusório e ideológico 'enxugamento da máquina pública'.

Vem acrescentar a esse contexto da censura ideológica de Estado contra o sujeito ecopolítico, o comprometedor Programa Nacional das Escolas Cívico-Militares, do Ministério da Educação, destinado especificamente a implantar a pedagogia da ordem e disciplina no batalhão da juventude brasileira que convive com a realidade escolar destinada majoritariamente à classe trabalhadora; reforçando o poder de controle do aparelho ideológico de Estado exatamente sobre aqueles que devem manter-se aprisionados pela opressão e exclusão, inculcando a obediência servil como expressão acabada deste singular patriotismo nacional, domesticando a desobediência civil como expressão ética do agir humano. Importa observar que Bolsonaro qualificou a disciplina na escola com tutela de militares, como "fundamental para o desenvolvimento do país" ${ }^{24}$. Importa observar também, que a falta de disciplina entre os alunos na escola nunca foi exatamente o problema mais grave a se enfrentar por meio de novas políticas públicas federais de Educação como esta, que vêm dar garantias de manutenção da ordem e disciplina para o jovem dentro da escola pública periférica.

Acrescenta-se por fim, a esse cenário de múltiplos controles ideológicos do Estado sobre esse caráter subversivo que dá ânimo à ação política, adicionando assim outra lamentável camada trágica sobre o amplo e multifacetado drama social ecopolítico brasileiro agora particularmente dentro do campo da Educação Ambiental -, o desmonte da Política Nacional de Educação Ambiental (PNEA).

O presente momento histórico aponta para uma ruptura radical da tendência histórica da Educação Ambiental brasileira; fenômeno sinalizado primeiro pela surpreendente extinção das institucionalidades administrativas da PNEA nos organogramas do Ministério da Educação e do Meio Ambiente: o Órgão Gestor da PNEA foi desligado. Segundo, pela interrupção do modelo democrático de gestão pública da PNEA com suas instâncias políticoadministrativas, a exemplo do Comitê Assessor da PNEA, que teve suas funções suspensas. Com isso, todo o contato do Estado com a sociedade civil se desfez. E terceiro, pela descontinuidade da árdua evolução da trajetória conceitual da Educação Ambiental, compreendida pelo menos desde os anos 90 como um ato político de formação cidadã para a participação social na defesa ambiental, que conseguiu ultrapassar o reducionismo biológico da simples 'conscientização ambiental' individual e das fórmulas pedagógicas conteudistas e

\footnotetext{
${ }^{24}$ http://portal.mec.gov.br/component/content/article?id=79931
} 
Ensino, Saúde e Ambiente - Número Especial, pp. 44-88, Junho. 2020

normativas, embora ainda não tenha traduzido tal conteúdo na criação de políticas públicas declaradamente orientadas por essa perspectiva de formação de um sujeito ecopolítico.

Se o ativismo ambiental não será tolerado, tampouco a formação de ativistas ambientais será admitida. Talvez aí resida parte da explicação da suspensão das atividades sobre Educação Ambiental no governo federal. A Educação Ambiental brasileira pode ter sofrido essa radical inflexão no seu rumo histórico justamente porque ela tem o potencial de ser uma grande escola de formação de ativistas ambientais 'xiitas'. O Estado pode ter encerrado os programas e ações federais da Educação Ambiental na lógica do desaparelhamento ideológico para interromper a possibilidade de incentivar a formação de sujeitos ecopolíticos.

Ocorre que a interrupção na gestão da PNEA provocada por essa descontinuidade política com a instalação do novo governo federal, não necessariamente significa um problema em função da perda desse espaço político absolutamente central e imprescindível. Com o encerramento das atividades do Órgão Gestor da PNEA, nenhuma mensagem flui mais por este sistema educacional. Nem a mensagem crítica, libertária e emancipatória; mas também não a mensagem domesticadora e disciplinar. Ou seja: para a fração crítica do campo da Educação Ambiental, a interrupção dos programas e ações da PNEA pode representar um front a menos para se preocupar com o bombardeio do controle ideológico de Estado. A sociedade de certa forma fica imune ao trabalho de cooptação ideológica que poderia seguir exercendo sua influência na conversão dos educandos em sujeitos dóceis e funcionais ao sistema, se a energia da PNEA fosse religada novamente.

É precisamente nessa conjuntura de súbito desmonte completo da Educação Ambiental no governo federal, com a também despropositada suspensão de interlocução democrática, e na esperança do protesto mobilizado pela ação política de oposição à ordem imposta, que tão logo o novo governo tomou posse, educadores ambientais de todo o país criaram o OBSERVARE, um movimento social que se constitui político-pedagogicamente como um observatório militante de políticas públicas em Educação Ambiental, função desempenhada no pleno exercício cidadão do controle social sobre o Estado.

É nesse contexto, portanto, que nossa bandeira de luta é a da firme convicção que seguiremos empenhados com o compromisso com a Educação Ambiental que se faz no convívio democrático e em permanente diálogo com a sociedade.

Seguiremos empenhados com a renovação dos quadros dos militantes ambientais que compreendem a necessidade de intervir político-pedagogicamente nos fundamentos do mecanismo da insustentabilidade. 
Ensino, Saúde e Ambiente - Número Especial, pp. 44-88, Junho. 2020

Seguiremos empenhados em formar sujeitos ecopolíticos que possuem as habilidades, conhecimentos e valores para prosseguir na luta pelo direito a um outro modelo de desenvolvimento para além do capital.

Seguiremos empenhados na formação de atores políticos, com plena capacidade de leitura crítica da realidade, com plena capacidade de indignação e de mobilização subversiva em oposição contra uma ordem socioambiental injusta e predatória.

Seguiremos empenhados na formação de eco cidadãos que mantenham vivos o direito constitucional de expressão política e o espírito da luta política contra o saque do patrimônio ambiental brasileiro.

Seguiremos empenhados em trabalhar pela manutenção de uma Educação Ambiental que embora minoritária, já superou o reducionismo do modelo conservador há décadas, e que almeja a formação de humanos empoderados e interessados pelo fortalecimento da participação social na gestão do patrimônio social e ambiental brasileiro.

Estamos conscientes que o desmonte da Educação Ambiental brasileira é proposital e faz parte do projeto político do regime Bolsonaro de quebrar todas as engrenagens socioeducativas que atuam na formação de quadros da militância política, aí incluído ativismo ecopolítico. A Educação Ambiental brasileira ganhou projeção mundial pela sua capacidade de imaginar a formação de ativistas ambientais, superando o clássico reducionismo que insistia na formação de um sujeito com consciência ecológica limitada à sua esfera privada no mundo doméstico, sem qualquer consciência política. A Educação Ambiental brasileira, entranhada pela bênção da pedagogia freireana, tem plenas condições de formar eco cidadãos com consciência crítica, que mantêm vivo seu potencial de indignação e contestação contra todas as formas de opressão, injustiça e desigualdade.

Então vamos lá: não deixe de reciclar, nem de economizar água, nem de se preocupar com os hábitos de consumo. Não deixe de buscar uma alimentação saudável e orgânica. Sobretudo não deixe de visitar parques e nutrir a alma com a paz e tranquilidade da natureza selvagem, mas terapêutica. Não deixe de anunciar com toda disciplina, o caminho da sustentabilidade; mas não deixe especialmente, de denunciar o caminho da insustentabilidade, porque por enquanto, são muito poucos esses ativistas indisciplinados que assumiram a responsabilidade da oposição ecopolítica. Traga a ação política para o seu estilo de vida ecológico; porque ela tem o poder da pressão coletiva capaz de realmente mudar as coisas. E vamos combinar: a sensação de impotência e paralisia que vêm tomando conta de muitas mentes apaixonadas pela natureza e preocupadas com as injustiças socioambientais, é também uma manifestação explícita do que essa sensação de impotência e incapacidade para reverter 
Ensino, Saúde e Ambiente - Número Especial, pp. 44-88, Junho. 2020

definitiva e imediatamente esse quadro da completa desordem socioambiental, deriva justamente do atingimento do limite da ação individual. Daqui para frente, é o poder da ação política que carrega a potência adequada para a superação do desafio.

Diz o ditado popular que o governo só atende quem aperta mais forte a campainha. Então, em tempos de retrocesso ambiental combinado com a iminência do colapso climático, a contestação ecopolítica não precisaria estar incorporada na rotina de um cidadão que se reconhece como preocupado com a causa ambiental, para guiar os tomadores de decisão a seguir por outro caminho, abandonando definitivamente essa absurda trajetória ecocida, como têm demonstrado Greta Thunberg neste curto mas intenso e inesquecível primeiro semestre de 2019 ?

\section{Posfácio: para não se perder na encruzilhada da Educação Ambiental}

Um mês após as manifestações com protestos espalhados por todo o país ao longo da semana do meio ambiente, em julho de 2019, a Associação Nacional dos Servidores da Carreira de Especialista em Meio Ambiente (ASCEMA) convocou mais um grande ato de protesto para o dia 15 de agosto, intitulado "Fora Ministro da Destruição do Meio Ambiente". Marcando esse contexto, a exigência da imediata correção do rumo da (des) política ambiental de Bolsonaro, começando pela destituição do ministro que até então só havia advogado contra a causa ambiental.

Mas a questão que fica é: as pessoas presentes nas manifestações de rua passaram a compreender atos dessa natureza como ações ecologistas inadiáveis em prol da sustentabilidade? Compreenderam que a ação coletiva integra e complementa o vocabulário do cidadão ecologicamente atuante?

O campo da Educação Ambiental percebeu que a mudança da conjuntura ecopolítica implicou na necessidade de se promover um rearranjo político-pedagógico para lidar com esta nova realidade? Os processos educadores acerca da temática ambiental passarão a partir deste drama social a formar sujeitos ecológicos imbuídos desse espírito de luta e protesto, ou seja, formar sujeitos politicamente atuantes para agir na esfera pública? O drama social ecopolítico brasileiro servirá como uma expressiva lição a aprender, para superar o desafio dessa nova realidade?

No histórico e infindável dilema existencial de ser ou não ser uma disciplina, a Educação Ambiental acabou sendo disciplinada. Sua vontade de transgredir a forma do compartimento disciplinar não lhe permitiu perceber que seu conteúdo acabou sendo 
Ensino, Saúde e Ambiente - Número Especial, pp. 44-88, Junho. 2020

domesticado. Devidamente disciplinado. E assim permaneceu capturada pela armadilha paradigmática, conceito criado por Guimarães (2006), para expressar a situação quando o ato pedagógico engrena sempre a mesma lógica, contínua e obstinadamente, reproduzindo acrítica e passivamente incorporados, sempre os mesmos objetivos de aprendizagem determinados pela forma capitalista de praticar a Educação Ambiental. Ao se pensar em Educação Ambiental no âmbito dos resíduos sólidos por exemplo, automática e exclusivamente se apresenta $\mathrm{o}$ ato pedagógico convencional da aprendizagem do comportamento correto de destinar o lixo, agora repaginado com o pomposo nome de resíduo, para distinguir o inservível da nova mercadoria a circular na economia da logística reversa, movimentada pela reciclagem. A armadilha paradigmática é um artefato explosivo do modelo conservador de Educação, que inculca a ideia fragmentária de que a causa primordial da crise ambiental resulta preponderantemente de um desvio comportamental individual. Portanto, a solução do impasse ecológico na sociedade de classe é a responsabilização desproporcional do indivíduo atomizado na horda populacional em relação à desresponsabilização da elite político-econômica e do próprio Estado. Implicitamente culpabilizando o indivíduo, ele deve obediente e disciplinadamente passar por um processo de purificação para expurgar a culpa e então modificar seu condenável comportamento, sob o critério da moral dos donos do poder. Disciplinado, esse cidadão assujeitado se torna incapaz de ver algo além da estreita janela desta cela individual que é a armadilha paradigmática.

Só uma Educação Ambiental indisciplinada carrega a potencialidade de se evadir da armadilha paradigmática. Apenas uma Educação Ambiental desobediente, que não se submete dócil e facilmente, possui a habilidade necessária para desarmar essa armadilha paradigmática.

É no calor do apertado atravessamento nessa fatal encruzilhada das colossais chamas na Amazônia, da iminência do colapso climático, do estridente atrito do retrocesso ambiental, do choque geracional que separou os velhos habitantes humanos deste mundo dos que agora estão chegando e se estarrecendo com a irresponsabilidade da farra desenvolvimentista dos adultos que andaram pelo planeta e cagaram para seu futuro; e finalmente, da bomba de fragmentação individual de imposição da ordem e disciplina obediente; que enfim, com o coração aquecido do calor humano, a Educação Ambiental pode se reinventar saindo da doce anestesia domesticadora a que foi vítima, submetida pela armadilha paradigmática. Mas pode também ficar irremediavelmente presa ainda nesta armadilha, caso desperdice a chance oferecida pelo drama social ecopolítico para sair dessa submissão, se não estiver disposta a sair da zona de conforto oferecida pelo ethos consumista. 
Ensino, Saúde e Ambiente - Número Especial, pp. 44-88, Junho. 2020

As últimas linhas deste ensaio foram escritas na noite no dia 20 de setembro, logo após a marcha pelo clima na esplanada dos ministérios, como movimento coletivo articulado à manifestação global que ocorreu simultaneamente em mais de 150 países, nessa que foi mais uma famosa sexta-feira das greves juvenis pelo clima em 2019. Revigorado e nutrido pela energia contagiante do pertencimento coletivo mobilizado pela mesma causa.

Data estrategicamente definida, a véspera da Cúpula do Clima das Nações Unidas em Nova Iorque, exatamente para que o recado rebelde das milhares de vozes da indignação no protesto nas ruas, pudesse ser ouvido por quem realmente precisa ouvir mais. E fazer diferente. Eis a preciosa receita para não se perder na encruzilhada desta travessia da Educação Ambiental.

\section{Referências Bibliográficas}

AGUILERA, J.A. Ecologia, ciência subversiva. Caracas: Monte Avila Editores. 1980.

ALIER, J.M. O ecologismo dos pobres. São Paulo: Contexto. 2007.

ALTHUSSER, L. Ideologia e aparelhos ideológicos de Estado. Lisboa: Presença. 1970.

BOURDIEU, P.; PASSERON, J.C. A reprodução: elementos para uma teoria do sistema de ensino. $3^{\text {a }}$ ed. Rio de Janeiro: Francisco Alves. 1992.

CARRASCO, L. Máfia Verde: o ambientalismo a serviço do governo mundial. $10^{\text {a }}$ edição. Rio de Janeiro: Capax Dei. 2006.

CARVALHO, I.C.M. Educação ambiental: a formação do sujeito ecológico. São Paulo: Cortez. 2004.

DELINGPOLE, J. Os melancias: como os ambientalistas estão matando o planeta, destruindo a economia e roubando o futuro de vossos filhos. Rio de Janeiro: Topbooks. 2012.

FREIRE, P. Pedagogia da Indignação: cartas pedagógicas e outros escritos. São Paulo: Editora Unesp. 2000.

FREIRE, P. Pedagogia da Autonomia: saberes necessários à prática educativa. São Paulo: Paz e Terra. 1996.

GUIMARÃES, M. A armadilha paradigmática na educação ambiental. In: LOUREIRO, C.F.B.; LAYRARGUES, P.P.; CASTRO, R.S. de. (org): Pensamento complexo, dialética e educação ambiental. São Paulo: Cortez. pp. 15-29. 2006. 
Ensino, Saúde e Ambiente - Número Especial, pp. 44-88, Junho. 2020

LAYRARGUES, P.P. Antiecologismo no Brasil: reflexões ecopolíticas sobre o modelo do desenvolvimentismo-extrativista-predatório e a desregulação ambiental pública. In: OLIVEIRA, M.M.D.; MENDES, M.; HANSEL, C.M.; DAMIANI, S. (org): Cidadania, Meio Ambiente e Sustentabilidade. Caxias do Sul: EDUCS, p.325-356. 2017.

LAYRARGUES, P.P. Quando os ecologistas incomodam: a desregulação ambiental pública no Brasil sob o signo do antiecologismo. Revista Pesquisa em Políticas Públicas, n. 12, pp. 1-30. 2018 a.

LAYRARGUES, P.P. Subserviência ao capital: educação ambiental sob o signo do antiecologismo. Pesquisa em Educação Ambiental, 13(1):28-47. 2018 b.

LAYRARGUES, P.P. É só reciclar? Reflexões para superar o conservadorismo pedagógico reprodutivista da Educação Ambiental e resíduos sólidos. In: RUSCHEINSKY, A.; CALGARO, C.; WEBER, T. (org): Ética, Direito Socioambiental e Democracia. Caxias do Sul: EDUCS. p.194-211. 2018 c.

McCORMICK, J. Rumo ao Paraíso. Rio de Janeiro: Relume-Dumará. 1992.

MEADOWS, D. et al. Limites do crescimento. $2^{\mathrm{a}}$ ed. São Paulo: Perspectiva. 1978.

ORLEANS e BRAGANÇA, D.B. Psicose ambientalista: os bastidores do ecoterrorismo para implantar uma religião ecológica, igualitária e anticristã. São Paulo: Instituto Plínio Corrêa de Oliveira. 2012.

REIGOTA, M. O que é educação ambiental. São Paulo: Brasiliense. 1994.

SILVA, S.E.L.; SANTOS, R.S. Escusa de consciência e alternativas ao uso de animais no curso de Ciências Biológicas da Universidade Federal do Pará - UFPA. Revista Brasileira de Direito Animal, 7(11):79-95. jul.-dez. 2012.

TURNER, V. From ritual to theatre. New York: PAJ Publications. 1982

THOREAU, H.D. Walden. Porto Alegre: L\&PM. 2014.

THOREAU, H.D. Desobediência Civil. São Paulo: EDIPRO. 2016. 
Ensino, Saúde e Ambiente - Número Especial, pp. 44-88, Junho. 2020

\section{SOBRE O AUTOR}

Possui graduação em Ciências Biológicas, especialização em Planejamento e Educação Ambiental, mestrado em Psicossociologia de Comunidades e Ecologia Social e doutorado em Ciências Sociais. Trabalhou no Departamento de Educação Ambiental do Ministério do Meio Ambiente na gestão de Marina Silva. É Professor do curso de Gestão Ambiental da UnB e pesquisador do Laboratório de Investigações em Educação, Ambiente e Sociedade da UFRJ. 